\title{
FDICIA and Risk Shifting in the Banking Industry
}

\author{
SEOK-WeON LeE*
}

This is an empirical study that examines how the Federal Deposit Insurance Corporation Improvement Act (FDICIA) of 1991 in the U.S. banking industry affects the moral hazard risk-taking incentives of banks. We find that FDICIA appears to be effective in significantly reducing the systematic risk-taking incentives of the banks. Considering that the banks' asset portfolios are necessarily largely systematic risk-related, the significant decrease in their systematic risk-taking incentives provides some evidence of the effectiveness of FDICIA. However, with respect to the nonsystematic risk-taking behavior, the results generally indicate statistically insignificant decreases in the risk-taking incentives after FDICIA. To well-diversified investors who can diversify nonsystematic risk away, nonsystematic risk may not be a risk any more. However, to maintain a sound banking environment and to reduce the risk to individual banks, this result implies that regulatory agents should monitor the banks' nonsystematic risk-taking behavior more closely, as long as it is positively related to the banks' failures. We further test the change in the risk-taking incentives by partitioning the full sample into two groups: Banks with higher moral hazard incentives as those with larger asset size and lower capital ratio and banks with lower moral hazard incentives as those with smaller asset size and higher capital ratio. The main result for this test is that, with FDICIA, the decrease in the risk-taking incentives of the banks with higher moral hazard incentives (larger asset-size and lower capital-ratio banks) is less than that of the banks with lower moral hazard incentives (smaller asset-size and higher capital-ratio banks), with respect to both systematic and nonsystematic risk-taking measures. Furthermore, the change in the nonsystematic risk-taking incentives of the banks with higher moral hazard incentives is rather mixed, while their systematic incentives are decreased. These findings imply that the regulatory agents should allocate more time and effort toward monitoring the banks with higher moral hazard incentives with particular emphasis on their nonsystematic risk-taking behavior.

Keywords: Bank regulations, Risk-taking, Safety of banking industry, Bank size, Bank capital 


\section{INTRODUCTION}

I

n general, market forces prevent corporations from taking excessive risks. Debt holders demand interest rates high enough to compensate for higher default risk when a corporation holds a risky portfolio. Thus, it is difficult to exploit debt holders because the cost of debt increases with the risk factor of a corporation. This increased cost of funds to risky institutions would reduce incentives toward excessive risk-taking. The effectiveness of this market mechanism is limited in the banking sector, however, because of government-backed deposit insurance. Depositors no longer care about the soundness of their bank: in case of adversity, they look to the deposit insurance system and not to the resources of their bank. Thus most depositors, who are the major debt holders of banks, are indifferent about the risk factor of individual banks, and hence, do not demand higher interest rates from riskier banks. Depositors have little incentive to check the risk-taking behavior of their banks. Banks, therefore, could pursue riskier strategies without paying higher costs. Researchers agree that the bank failures of the 1970 s and 1980 s are attributed to these moral hazard risk-taking incentives of banks.

Regulators attempt to reduce moral hazard behavior by enforcing many regulatory provisions and constraints on banks. Of these, the Federal Deposit Insurance Corporation Improvement Act (FDICIA) of 1991 is the most important and comprehensive regulatory event in U.S. banking industry. It is believed to be a broad-sweeping legislative measure with many facets and implications for the banking industry. The FDICIA's main provisions are summarized below.

Exhibit 1. The Federal Deposit Insurance Corporation Improvement Act (FDICIA) of 1991

- Restricted coverage of brokered deposits: These will be insured only at well-capitalized institutions.

- Risk-based premiums: The act required the FDIC to institute risk-based premiums by 1994 .

- Restrictions on failure resolution: The FDIC must use a method of resolution that minimizes cost. The Act restricts the FDIC's freedom to choose among payouts, purchase and assumption, or bridge-bank assistance in resolving bank failures.

- Limitations on the "too big to fail" doctrine: After 1994, the FDIC may not reimburse uninsured deposits (those over $\$ 100,000$ and those overseas) unless failing to do so threatens the stability of the banking system. Such an exception may be made only with the prior agreement of both the Fed and the Treasury.

- Limitations on extended credit: The Fed may no longer provide extended credit to banks in trouble. If a bank does fail owing the Fed money, the Fed rather than the FDIC must take the loss. 
- Early intervention: Regulators must intervene earlier to limit the potential loss to the insurance fund. A new system of rating a bank's capitalization went into effect in December 1992. The lower a bank's rating on this scale, the tougher are the restrictions it faces. Regulators must close a bank if its leverage ratio falls below $2 \%$.

Despite these provisions, little empirical assessment has been made of its impact on the moral hazard behavior of banks. In this study, using a sample of 82 U.S. bank holding companies, we examine how the FDICIA affects the moral hazard risk-taking behavior of banks.

In the next section, we review the factors that are argued to affect the moral hazard risk-taking behavior of banks by the researchers in the literature. We describe the hypotheses to be tested and the basic regression model used to test them in Section 3. In section 4, we present the empirical results. Section 5 offers concluding comments.

\section{MORAL HAZARD RISK-TAKING BEHAVIOR OF BANKS}

\section{Moral Hazard Incentives of Stockholders}

As in non-financial corporations, limited liability gives bank stockholders an incentive to expropriate wealth from bondholders by increasing risk. Furthermore, since the government protects bondholders (depositors) from the consequences of bank risk-taking, their incentive to monitor and constrain risk-taking is weak. With limited liability, stockholders of a corporation can walk away without further losses when the net worth of the firm falls below zero. Stockholders can thus increase their wealth at the expense of debt holders by pursuing risky strategies. With high level of risk, it is more likely that the return from assets will turn out to be very high. The high level of risk also increases the possibility of an extremely low return. Limited liability, however, protects stockholders from incurring additional losses when once net worth falls below zero. In other words, with limited liability, it is more likely that losses from high risk-taking will be borne ultimately by debt holders, while the benefit from it will be captured by stockholders. Furthermore, government-backed deposit insurance makes the incentives of debt holders to monitor stockholders' behavior weak, and hence, banks could enjoy risk-insensitive funding costs and have greater risk-taking incentives than they would have if deposits were not insured.

Galloway, Lee and Roden (1997) find that the banks with a low ex-ante book value of capital ratio (at time t-1) take a significantly high ex-post risk (high standard deviation of stock returns at time $t$ ), indicating the existence of moral hazard risk-taking incentives of stockholders. Demsetz and Strahan (1997) find 
a contemporaneously significantly negative relationship between capital-to-asset ratio and risk-taking (standard deviation of stock returns). Gunther and Robinson (1990) find a significantly negative relationship between capital growth and loan growth, interpreting this result as a negative relationship between capital adequacy and risk-taking. McKenzie, Cole and Brown (1992) find that low capital thrifts undertake projects with low net present value to increase the variance of the return.

\section{Franchise Value}

In addition to tangible assets, firms have franchise value, which may be defined as the economic value of the future growth opportunity. If a bank fails, it loses its franchise value. That is, the owners of the bank cannot sell the franchise value once the bank is declared insolvent. Thus, a bank with a high franchise value has an incentive to avoid a riskier strategy. Instead, a bank that is insolvent on a book-value basis still has a valuable franchise that the FDIC could sell in a purchase and assumption (P\&A). This may explain why P\&A's are typically less costly than liquidations. Effective restrictions on entry and competition raise franchise value. When there is less competition, the probability of making higher profits would be high. Keeley (1990) argues that the increased competition in the banking sector in the 1980s reduces the franchise value of banks, and hence, increases their incentives to take risk. He finds that the banks with higher franchise values follow lower risk strategies by holding higher capital-to-asset ratios. Using a sample of 85 bank holding companies over 1971-1986, he finds a contemporaneous positive relationship between bank franchise value and bank capital-to-asset ratio, and he interprets this as a negative relationship between franchise value and risk. ${ }^{1}$ Galloway, Lee and Roden (1997), using a sample of 86 bank holding companies over 1977-1994, find that the banks with high ex-ante franchise value (at time t-1) take a significantly low ex-post risk (low standard deviation of stock returns at time $t$ ).

\section{Firm Size}

In testimony to Congress in September 1984, the Comptroller of the Currency declared that the 11 largest banks would not be allowed to fail because of the potential damage to the economy, though the names of the included banks were not explicitly specified. In the event of insolvency, the FDIC would bail them out, and no depositor or creditor would take a loss. This implies that for those banks, total deposit insurance would be provided. This policy came to be known as the "too-big-to-fail doctrine". With their costs of funds (deposit interest rates) no longer tied to their risk factor, those banks would have incentives to increase the risk of their operations.

Although the too-big-to-fail policy was originally applied to the 11 largest banks, if investors and bankers themselves believe that regulators are unwilling to let 
larger banks fail, then larger banks would have greater risk-taking incentives. Using 38 bank holding companies over 1978-1985, Saunders, Strock and Travlos (1990) find that, although insignificant, systematic equity risk is positively related to total asset size. ${ }^{2}$ Demsetz and Strahan (1997) find that, though larger bank holding companies are better diversified than smaller ones, they do not translate this advantage into less risk. Or rather, larger banks use their diversification advantage to operate with lower capital ratios and pursue riskier strategies with higher concentrations on consumer \& industry loans. Akhavein, Berger and Humphrey (1997) argue that the profit enhancing associated with larger banks' riskier strategies (shift in outputs from lower risk securities to higher risk loans) is the major motivation for bank-mergers.

\section{Ownership structure}

As discussed in 2.1, the incentive for limited liability stockholders to increase the risk of the firm is widely noted. However, the ability of a bank's stockholders to maximize the firm value depends in part on the preferences of the bank's managers. If managers' wealth is largely in nondiversifiable bank-specific forms, they may act in a risk-averse rather than a value-maximizing manner, in which case their optimal risk-taking would be less than that of stockholders. However, by giving managers stock or stock options in the banking firm, their interests will become more closely aligned with those of stockholders. Thus, stockholder-controlled banks (defined as banks whose managers hold a relatively large proportion of the banks' stock and act in the stockholder's value-maximizing interest) would pursue riskier strategies than the managerially-controlled banks (defined as banks whose managers hold a relatively small proportion of the banks' stock and act in their own utility-maximizing interests). Saunders, Strock and Travlos (1990) find that ownership structure (the degree of stockholder control by the proportion of stock held by managers) is significantly positively related to nonsystematic risks (standard deviation of stock returns and unsystematic risk), indicating that stockholder-controlled banks have greater risk-taking incentives. ${ }^{3}$ Similarly, Demsetz, Saidenberg and Strahan (1997) find a positive relationship between ownership structure and risk-taking, with respect to both systematic risk and standard deviation of stock returns.

However, in the literature, indications of the relationship between ownership structure and risk-taking are mixed. Some researchers argue that stockholding by managers who are not majority owners may actually increase their ability to resist stockholders' monitoring, rather than serve to align the interests of outside equity owners and managers. Thus, they predict a nonlinear relationship between ownership structure and risk-taking. For small insider holdings, the incentives of insiders (manager stockholder) become more aligned with those of the outsiders (stockholder, but no manager), and management does not have enough power to be entrenched. As insider concentration continues to rise, management becomes entrenched and 
their equity shares are large enough to stave off effective discipline from outside. A further increase in concentration aligns management interests with outsiders; management becomes essentially become the sole owners. Morck, Shleifer and Vishny (1988) find that as insider ownership rises to 5\%, Tobin's $\mathrm{q}$ increases; then $\mathrm{q}$ falls as insider concentration grows to 25\%; at higher levels, it rises again. McConnell and Servaes (1990) find a similar result. Gorton and Rosen (1995) present a game-theoretic model and find a non-monotonic relationship between insider holdings and bank risk-taking.

\section{TESTING MODEL AND HYPOTHESIS}

\section{Data and Sample}

The sample for this research consists of 82 bank holding companies for which data are available on both the Standard \& Poor's Stock Report and the Center for Research in Security Prices (CRSP) data tapes during the period 1988-1995. The Standard \& Poor's Stock Report contains year-end balance sheets and other financial data for the bank holding companies which are publicly traded in the New York Stock Exchange (NYSE), American Stock Exchange (ASE) and National Association of Securities Dealers Automated Quotations (NASDAQ).

From the Standard \& Poor's Stock Report, we obtain the data of capital-to-asset ratio, book value of share, asset size and loan-to-asset ratio. Daily stock return data are obtained from the CRSP data base. Daily returns are adjusted to account for dividend payouts and stock splits. Our analysis is based on those bank holding companies that traded every day (except for holiday) of each year's 4th quarter for the whole sample period. In the market model, each year, return on the market portfolio is measured using 4th quarter's daily return on S\&P 500.

In the case of mergers, we exclude both acquired banks and acquirers from the sample. If the profit enhancing associated with larger banks' riskier strategies is the major motivation for bank-mergers, including merger cases would make the empirical results biased. 4

In our sample of 82 banks, 38 banks are traded in the NYSE, 40 banks in the NASDAQ and 4 banks in the ASE.

\section{Risk-taking Measure}

In this study, we test our hypotheses for two interpretations of risk measures, the systematic and unsystematic. We believe that systematic risk is more germane to the fundamental ideas being examined, and include the unsystematic interpretation only for completeness. Our belief rests on the fact that the risky assets in the sample banks' portfolios are loans to large businesses, and the risk of these loans 
largely depends on the economy at large as reflected in the general course of the stock market. This risk is best captured by the systematic risk of the banks' equity beta estimated from the one-factor market model. ${ }^{5}$

As the proxy for the systematic risk-taking of the bank at time $t$, we define the systematic incremental risk of the bank $i$ at time $t$ as the systematic risk level of the bank at time $t+1\left(\beta_{i, t+1}\right)$ minus the systematic risk level of the bank at time $\mathrm{t}\left(\beta_{\mathrm{i}, \mathrm{t}}\right)$ : 6

Systematic incremental risk of the bank $\mathrm{i}$ at time $\mathrm{t}=\beta_{\mathrm{i}, \mathrm{t}+1}-\beta_{\mathrm{i}, \mathrm{t}}$

In the literature, $\beta_{\mathrm{t}}$, is widely used as a measure capturing the risk-taking incentives at time $\mathrm{t}$. High $\beta$ at time $\mathrm{t}$ means that the firm is in risky status at time $\mathrm{t}$. However, this does not necessarily imply that the firm has high risk-taking incentives at time $\mathrm{t}$. Or rather, high $\beta$ firm at time $\mathrm{t}$ might have low risk-taking incentives at time $\mathrm{t}$ to reduce its risk status. In other words, the risk level at time $\mathrm{t}, \beta_{\mathrm{t}}$, may be a control (or, base) variable for choosing the firm's optimal risk-taking at time $\mathrm{t}$, rather than a variable reflecting the risk-taking incentives at time $\mathrm{t}$. Galloway, Lee and Roden (1997) treat this problem explicitly, and employ a lagged model rather than a contemporaneous one, though they do not include the risk level as a control variable for choosing the firm's subsequent optimal risk-taking. In their model, risk-taking (dependent variable in the regression equation) is measured at time $t$, and independent variables are measured at time $t-1$.

Similarly, as the proxy for the nonsystematic risk-taking of the bank at time $t$, we define the nonsystematic incremental risk of the bank $i$ at time $t$ as follows: ${ }^{7}$

Nonsystematic incremental risk of the bank $i$, at time $t=\sigma_{i, t+1}-\sigma_{i, t}$

$$
\sigma^{2}\left(\varepsilon_{\mathrm{i}, \mathrm{t}+1}\right)-\sigma^{2}\left(\varepsilon_{\mathrm{i}, \mathrm{t}}\right)
$$

, where $\sigma_{\mathrm{i}, \mathrm{t}}$ is the standard deviation of daily stock returns of the bank $\mathrm{i}$ at time t. $\sigma^{2}(\mathrm{i}, \mathrm{t})$ is the residual variance of daily stock returns of the bank $\mathrm{i}$ at time $t$ estimated from the one factor market model.

\section{Specification of the Variables Affecting the Risk-taking Incentives of Banks and the Testable Hypotheses Associated with FDICIA $^{8}$}

\section{(1) Moral Hazard Incentives of Stockholders}

The moral-hazard-incentives-of-stockholders hypothesis (limited liability hypothesis) predicts that as capital ratio is lower, risk-taking would be greater. Thus, if the moral-hazard-incentives-of-stockholders hypothesis dominates, capital ratio and incremental risk would be negatively related before the FDICIA.

However, if those activities result in heavier regulatory oversights and higher 
costs after the FDICIA, a tendency of the banks with lower capital ratio to pursue riskier strategies would be weaker. Thus, after the FDICIA, the negative relationship between capital ratio and incremental risk would be expected to be weaker.

\section{(2) Franchise Value}

The franchise-value hypothesis predicts that as franchise value is lower, risk-taking would be greater. Thus, if the franchise-value hypothesis dominates, franchise value and incremental risk would be negatively related before FDICIA.

However, if those activities result in heavier regulatory oversights and higher costs after the FDICIA, the tendency of the banks with lower franchise value to pursue riskier strategies would be weaker. Thus, after FDICIA, the negative relationship between franchise value and incremental risk would be expected to be weaker. As the measure of the franchise value, we use the average of the 4th quarter market value of stock minus year-end book value of stock.

\section{(3) Firm Size}

Though the "Too-Big-To-fail-Policy" was originally applied to the 11 largest banks in 1984, if investors and bankers themselves believe that regulators are unwilling to let larger banks fail because of the potential damage to the economy, it appears that as asset size is larger, risk-taking would be greater. Thus, if the "too-big-to-fail-policy" hypothesis dominates, asset size and incremental risk would have been positively related before the FDICIA.

However, if those activities result in heavier regulatory oversights and higher costs after the FDICIA, a tendency of the banks with larger asset size to pursue riskier strategies would be weaker. Thus, after the FDICIA, the positive relationship between asset size and incremental risk would be expected to be weaker.

\section{(4) Current (Base Period's) Risk Level}

One of the important factors determining a bank's optimal risk-taking would be how much risk the bank is currently exposed to. The relationship between the current risk level (whatever the risk measure may be) and risk-taking is not a priori definite, because the overall risk factor of banks were not explicit targets of regulations before the FDICIA. However, if the bank with a currently high risk level tends to reduce its risk status, the current risk level and its incremental risk would have been negatively related before the FDICIA.

After the FDICIA, since regulatory oversights and constraints would be imposed more heavily on the banks with higher risk factors through many provisions of the FDICIA such as risk-based insurance premiums, riskier banks should put more effort into improving their risk status. Therefore, after the FDICIA, the relation 
between current risk level and subsequent incremental risk would be expected to be more negative.

\section{(5) Economic Condition}

Since bank holding companies operate throughout the whole country with various kinds of financial instruments, we include the growth rate of GDP9 to control the impact of economic conditions on the banks' risk-taking incentives.

\section{Specification of the Testing Models}

To examine how the banks' systematic risk-taking incentives have changed after the FDICIA, we estimate the following pooled time-series cross-sectional regression equation (1) including the FDICIA dummy interaction variables ${ }^{10}$ : the FDICIA dummy variable D takes 1 after FDICIA, 1992-1995, and 0 before FDICIA, 1988-1991.

$$
\begin{aligned}
\beta_{\mathrm{i}, \mathrm{t}+1}-\beta_{\mathrm{i}, \mathrm{t}}=\mathrm{b}_{00} & +\mathrm{b}_{01} * \mathrm{D}+\mathrm{b}_{10}(\text { Capital-to-asset })_{\mathrm{i}, \mathrm{t}}+\mathrm{b}_{11} * \mathrm{D} *(\text { Capital-to-asset })_{\mathrm{i}, \mathrm{t}} \\
& +\mathrm{b}_{20}(\text { Market-book })_{\mathrm{i}, \mathrm{t}}+\mathrm{b}_{21} * \mathrm{D} *(\text { Market-book })_{\mathrm{i}, \mathrm{t}} \\
& +\mathrm{b}_{30}\left(\text { Asset }_{\mathrm{i}, \mathrm{t}}+\mathrm{b}_{31} * \mathrm{D} *(\text { Asset })_{\mathrm{i}, \mathrm{t}}\right. \\
& +\mathrm{b}_{40}\left(\beta_{\mathrm{i}, \mathrm{t}}\right)+\mathrm{b}_{41} * \mathrm{D} *\left(\beta_{\mathrm{i}, \mathrm{t}}\right)+\mathrm{b}_{5}(\mathrm{GDP} \text { growth })_{\mathrm{t}}+\varepsilon_{\mathrm{i}, \mathrm{t}}
\end{aligned}
$$

, where $\beta_{\mathrm{i}, \mathrm{t}}$ is estimated from the 4th quarter daily stock returns of the bank $i$, in year $t$. (Capital-to-asset $)_{i, t}$ and (Asset $)_{i, t}$ is the bank i's year t-end values. (Market-book) $)_{i, t}$ is the average of the bank i's year t's 4th quarter (market) stock price minus year $t$ 's end book value of share.

We test the null hypothesis of no change in the risk-taking incentives of banks with the FDICIA by examining the sign and statistical significance of the coefficient on the FDICIA dummy interaction variables. $b_{11}, b_{21}, b_{31}, b_{41}$. $b_{10}(i=0, \cdots, 4)$ represents the slope coefficient for the pre-FDICIA period. The slope coefficient for the post-FDICIA period is the sum of $b_{i 0}$ and $b_{i 1} .{ }^{11}$

The hypothesis described in 3.3. implies the following restrictions on the coefficients on the FDICIA dummy interaction variables, $b_{11}, b_{21}, b_{31}, b_{41}$.

Hypothesis $1: \mathrm{b}_{11}>0, \mathrm{~b}_{21}>0, \mathrm{~b}_{31}<0, \mathrm{~b}_{41}<0$.

Similarly, how FDICIA affects the banks' nonsystematic risk-taking incentives is examined by estimating the following two equations (2) and (3).

$$
\begin{aligned}
& \sigma_{\mathrm{i}, \mathrm{t}+1}-\sigma_{\mathrm{i}, \mathrm{t}}=\mathrm{b}_{00}+\mathrm{b}_{01} * \mathrm{D}+\mathrm{b}_{10}(\text { Capital-to-asset })_{\mathrm{i}, \mathrm{t}}+\mathrm{b}_{11} * \mathrm{D} *(\text { Capital-to-asset })_{\mathrm{i}, \mathrm{t}} \\
& +b_{20}(\text { Market-book })_{i, t}+b_{21} * \mathrm{D} *(\text { Market-book })_{i, t} \\
& +b_{30}\left(\text { Asset }_{i, t}+b_{31} * \mathrm{D} *\left(\text { Asset }_{i, t}\right.\right. \\
& +\mathrm{b}_{40}\left(\sigma_{\mathrm{i}, \mathrm{t}}\right)+\mathrm{b}_{41} * \mathrm{D} *\left(\sigma_{\mathrm{i}, \mathrm{t}}\right)+\mathrm{b}_{5}(\mathrm{GDP} \text { growth })_{\mathrm{D}_{\mathrm{i}}}+\varepsilon_{\mathrm{i}, \mathrm{t}}
\end{aligned}
$$




$$
\begin{aligned}
\sigma^{2}\left(\varepsilon_{\mathrm{i}, \mathrm{t}+1}\right)-\sigma^{2}\left(\varepsilon_{\mathrm{i}, \mathrm{t}+1}\right)=\mathrm{b}_{00} & +\mathrm{b}_{01} * \mathrm{D}+\mathrm{b}_{10}(\text { Capital-to-asset })_{\mathrm{i}, \mathrm{t}}+\mathrm{b}_{11} * \mathrm{D} *(\text { Capital-to-asset })_{\mathrm{i}, \mathrm{t}} \\
& +\mathrm{b}_{20}(\text { Market-book })_{\mathrm{i}, \mathrm{t}}+\mathrm{b}_{21} * \mathrm{D} *(\text { Market-book })_{\mathrm{i}, \mathrm{t}} \\
& +\mathrm{b}_{30}(\text { Asset })_{\mathrm{i}, \mathrm{t}}+\mathrm{b}_{31} * \mathrm{D} *(\text { Asset })_{\mathrm{i}, \mathrm{t}} \\
& +\mathrm{b}_{40}\left(\sigma^{2}\left(\varepsilon_{\mathrm{i}, \mathrm{t}}\right)+\mathrm{b}_{41} * \mathrm{D} *\left(\sigma^{2}\left(\varepsilon_{\mathrm{i}, \mathrm{t}}\right)\right)+\mathrm{b}_{5}(\mathrm{GDP} \text { growth })_{\mathrm{t}}\right. \\
& +\varepsilon_{\mathrm{i}, \mathrm{t}}
\end{aligned}
$$

, where $\sigma_{i, t}$ is estimated from the 4th quarter daily stock returns of the bank $i$, in year $t$ and $\left(\sigma^{2}\left(\varepsilon_{i, t}\right)\right)$ is estimated from the one factor market model using the 4th quarter daily stock returns of the bank $i$, in year $t$.

\section{EMPIRICAL RESULTS BASED ON THE FULL SAMPLE}

\section{Summary Statistics}

Table 1 presents the sample descriptive statistics of the 82 sample banks for the whole sample period (1988-1995). The bank holding companies in the sample range from $\$ 237$ million to $\$ 250$ billion in assets, averaging $\$ 7.8$ billion in assets. The average capital-to-asset ratio is 7.2 percent, ranging from 2 percent to 15.5 percent. The average of daily stock returns is 0.6861 , ranging from -1.7243 to 3.3247. The average $\beta$ standard deviation of daily stock returns is 0.0279 , ranging from 0.0058 to 1.1482 . The average residual variance of daily stock returns (estimated from the market model, using daily return on S\&P 500) is 0.0077 , ranging from 0.00003 to 1.2696 . The average loan-to-asset ratio is 67.11 percent, ranging from 13 percent to 95.15 percent.

Table 2 presents the means and variances of the sample banks' risk characteristic variables and some macro variables. T-statistics are based on the null hypothesis that the means of the variables are equal between the pre- and post-FDICIA period. F-statistics are based on the null hypothesis that the variances of the variables are equal between the pre- and post-FDICIA period.

The second column of the Table 2 reveals that the mean of the capital ratio and franchise value increase significantly from the pre-FDICIA to post-FDICIA period, indicating that the banks seemed to try to make their risk-taking (or, operating) structures more conservative after the FDICIA. However, in most cases the difference in the risk level mean and incremental risk before and after the FDICIA is statistically insignificant. Of course, comparing the absolute values of the above variables before and after the FDICIA is not be the absolute measure for evaluating the effectiveness of the FDICIA because, by this test, we cannot control the many factors affecting the risk-taking behavior of banks. For example, if economic conditions were much better after the FDICIA than before, the overall risk-taking of banks would not decrease (or, would increase) after the FDICIA, even though the FDICIA itself might be effective. 


\section{TABLE 1.}

Sample descriptive statistics for the whole sample period (1988-1995).

The table shows the sample descriptive statistics (mean, median, maximum, minimum and variance of the variables) of the 82 sample banks for the whole sample period (1988-1995).

\begin{tabular}{l|r|r|r|r|r}
\hline & Mean & Mean & Maximum & Minimum & Variance \\
\hline Capital ratio & 0.0717 & 0.0673 & 0.1553 & 0.02 & 0.0005 \\
Franchise value & 12.4876 & 8.4872 & 156.62 & -149.9 & 412.00 \\
Asset size(in Million \$) & 23680.7 & 7802.5 & 250254 & 235 & $1.26 \mathrm{E}+09$ \\
$\beta_{\mathrm{i}, \mathrm{t}+1}-\beta_{\mathrm{i}, \mathrm{t}}$ & -0.0451 & -0.0472 & 3.214 & -3.291 & 5.58 \\
$\beta_{\mathrm{i}, \mathrm{t}}$ & 0.6861 & 0.5418 & 3.3247 & -1.7243 & 3.26 \\
$\sigma_{\mathrm{i}, \mathrm{t}+1}-\sigma_{\mathrm{i}, \mathrm{t}}$ & 0.0004 & -0.0005 & 1.1533 & -1.1328 & 0.0109 \\
$\sigma_{\mathrm{i}, \mathrm{t}}$ & 0.0279 & 0.0187 & 1.1482 & 0.0058 & 0.0045 \\
$\sigma^{2}\left(\varepsilon_{\mathrm{i}, \mathrm{t}+1}\right)-\sigma^{2}\left(\varepsilon_{\mathrm{i}, \mathrm{t}}\right)$ & -1.0567 & $-1.3 \mathrm{E}-05$ & 1.3511 & -1.2694 & 0.0139 \\
$\sigma^{2}\left(\varepsilon_{\mathrm{i}, \mathrm{t}}\right)$ & 0.0077 & 0.0003 & 1.2696 & $3.15 \mathrm{E}-05$ & 0.0051 \\
${\text { (Loan-to-asset })_{i, \mathrm{t}+1}}_{-}$(Loan-to-asset $)_{i, \mathrm{t}}$ & -0.0036 & 0.0008 & 0.3291 & -0.9397 & 0.0061 \\
(Loan-to-asset $)_{i, \mathrm{r}}$ & 0.6711 & 0.6761 & 0.9519 & 0.1299 & 0.0240 \\
Number of observation & 656 & 656 & 656 & 656 & 656 \\
\hline
\end{tabular}

\section{TABLE 2.}

Sample descriptive statistics before and after the FDICIA.

The table shows the mean and variance of the risk characteristic variables for pre (1988-1991) and post (1992-1995)- FDICIA period. T-statistics are based on the null hypothesis that the means of the risk characteristic variables for the pre- and post- FDICIA period are equal. F-statistics are based on the null hypothesis that the variances of the risk characteristic variables for the pre- and post- FDICIA period are equal. *** indicates statistical significance at the $1 \%$ level, $* *$ indicates statistical significance at the $5 \%$ level, * indicates statistical significance at the $10 \%$ level.

\begin{tabular}{|c|c|c|c|c|c|c|c|}
\hline & $\begin{array}{c}\text { Mean } \\
\text { Before } \\
\text { FDICIA }\end{array}$ & & $\begin{array}{c}\text { Mean } \\
\text { After } \\
\text { FDICIA } \\
\end{array}$ & T-statistic & $\begin{array}{c}\text { Variance } \\
\text { Before } \\
\text { FDICIA }\end{array}$ & $\begin{array}{c}\text { Variance } \\
\text { After } \\
\text { FDICIA }\end{array}$ & F-statistic \\
\hline Capital ratio & 0.0669 & & 0.0805 & $-4.42 * * *$ & $0.0005<$ & 0.0019 & $4.02 * * *$ \\
\hline Franchise value & 8.9778 & & 17.1674 & $-4.94 * * *$ & $397.71>$ & 378.92 & 1.05 \\
\hline Asset size & 19207 & $<$ & 27591 & $-2.39 * *$ & $1.1 \mathrm{E}+09<$ & $2.21 E+09$ & $2.04 * * *$ \\
\hline$\beta_{\mathrm{i}, \mathrm{t}+1}-\beta_{\mathrm{i}, \mathrm{t}}$ & -0.0387 & $>$ & -0.0536 & 0.0149 & $2.3126<$ & 9.6752 & $4.18 * * *$ \\
\hline$\beta_{\mathrm{i}, \mathrm{t}}$ & 0.6149 & $<$ & 0.7811 & -1.11 & $0.5279<$ & 5.0588 & $9.58 * * *$ \\
\hline$\sigma_{\mathrm{i}, \mathrm{t}+1}-\sigma_{\mathrm{i}, \mathrm{t}}$ & -0.0021 & $<$ & 0.0037 & -0.66 & $0.0039<$ & 0.0154 & $3.84 * * *$ \\
\hline$\sigma_{i, \mathrm{t}}$ & 0.0278 & $<$ & 0.0280 & -0.04 & $0.0004<$ & 0.0103 & $25.81 * * *$ \\
\hline$\sigma^{2}\left(\varepsilon_{\mathrm{i}, t+1}\right)-\sigma^{2}\left(\varepsilon_{\mathrm{i}, \mathrm{t}}\right)$ & -1.8572 & $<$ & 0.0107 & -1.05 & $1.037<$ & 0.0271 & $3.83 * * *$ \\
\hline$\sigma^{2}\left(\varepsilon_{\mathrm{i}, t}\right)$ & 0.0011 & $<$ & 0.0164 & $-1.68 *$ & $5.2 \mathrm{E}-06<$ & 0.0204 & $4.06^{* * *}$ \\
\hline $\begin{array}{l}\text { (Loan-to-asset })_{i, \mathrm{t}+1} \\
\quad-(\text { Loan-to-asset })_{\mathrm{i}, \mathrm{t}}\end{array}$ & -0.0081 & & 0.0024 & -1.46 & $0.0027<$ & 0.0107 & $4.01 * * *$ \\
\hline (Loan-to-asset $)_{\mathrm{i}, \mathrm{t}}$ & 0.6766 & & 0.6631 & 0.96 & $0.0229<$ & 0.0311 & 1.36 \\
\hline GDP & 5835.9 & $<$ & 6914.2 & $-4.09 * * *$ & $113217<$ & 123127 & 1.09 \\
\hline Return on S\&P 500 & 0.1224 & $<$ & 0.1283 & -0.05 & $0.00012>$ & $3.19 \mathrm{E}-05$ & \\
\hline
\end{tabular}


The third column of the table shows that the variances of the banks' capital ratio, asset size, risk level and incremental risk are significantly higher after the FDICIA. Considering that the variance of return on the S\&P 500 (market) has been significantly lower after the FDICIA, it appears that, after the FDICIA, the banks have adjusted and changed their risk-taking (or, operating) structures more actively than before.

\section{Correlation Test}

Table 3 presents the results of the Pearson correlation test between the banks' risk characteristic variables, for the whole sample period (1988-1995), pre(1988-1991) and post-FDICIA period (1992-1995). Firstly, the table indicates that the correlations for the whole sample period between the capital-to-asset ratio, franchise value, asset size, and the risk level $(\beta)$ are very low. Thus, there would be no multicollinearity problems in the following regression tests using those variables as the independent variables.

\section{TABle 3.}

This table shows the result from the Pearson correlation test between risk characteristic variables. The first number is the correlation for the whole sample period (1988-1995). The second number is the correlation for pre- FDICIA period (1988-1991). The third number is the correlation for post- FDICIA period (1992-1995). *** indicates statistical significance at the $1 \%$ level, $* *$ indicates statistical significance at the $5 \%$ level, * indicates statistical significance at the $10 \%$ level.

\begin{tabular}{|c|c|c|c|c|}
\hline & $\begin{array}{l}\text { (Capital-to-asset } \\
\text { ratio) } \mathrm{i}, \mathrm{t}\end{array}$ & (Franchise value $)_{i, t}$ & $(\text { Asset size })_{\mathrm{i}, \mathrm{t}}$ & $\beta_{\mathrm{i}, \mathrm{t}}$ \\
\hline $\begin{array}{l}\text { (Capital-to-asset } \\
\text { ratio })_{i, t}\end{array}$ & 1 & $\begin{array}{l}0.0995 * * \\
0.2289 * * * \\
-0.0449\end{array}$ & $\begin{array}{l}-0.1801 * * * \\
-0.2977 * * * \\
-0.1669 * *\end{array}$ & $\begin{array}{l}-0.0474 \\
-0.2659 * * * * \\
-0.0154\end{array}$ \\
\hline$(\text { Franchise value })_{i, t}$ & & 1 & $\begin{array}{l}0.114 * * \\
0.0228 \\
0.1629 * *\end{array}$ & $\begin{array}{l}-0.0124 \\
-0.2144 * * * \\
0.0559\end{array}$ \\
\hline$(\text { Asset } \text { size })_{i, \mathrm{t}}$ & & & 1 & $\begin{array}{l}0.0979 * * \\
0.3339 * * * \\
0.0271\end{array}$ \\
\hline$\beta_{\mathrm{i}, \mathrm{t}}$ & & & & 1 \\
\hline
\end{tabular}

The results in table show that capital ratio had a significantly positive correlation with franchise value, a significantly negative correlation with asset size, and a significantly negative correlation with $\beta$, before the FDICIA. These results are the same as expected, because low capital ratio, low franchise value, large asset size, and high $\beta$, all indicate that the bank pursues riskier strategies. Thus, this result would imply that banks could maintain excessively risky structures before the FDICIA. However, it is seen that those tendencies became weaker after the FDICIA ( $\rho_{\text {capital }}$ ratio, franchise value from $0.2289 * * *$ to $-0.0449, \rho_{\text {capital ratio,asset from }-0.2977 * * * \text { to }}$ $-0.1669 * *, \rho_{\text {capital ratio, }}$ from $-0.2659 * * *$ to -0.0154$)$. 
It is also seen that franchise value had a significantly negative correlation with $\beta$ before the FDICIA. This result is the same as expected, because both low franchise value and high $\beta$ indicate that the bank pursues riskier strategies. However, after FDICIA, this relationship became weaker, indicating that the banks' behavior has become more conservative.

Asset size had a significantly positive correlation with $\beta$ before the FDICIA. This result is the same as expected, because both large asset size and high $\beta$ indicate that the bank pursues riskier strategies. Thus, the "too-big-to-fail-policy" hypothesis, implying that larger banks tend to pursue riskier strategies, is supported. However, consistent with the hypothesis, the correlation became more negative after the FDICIA (from $0.3339 * * *$ to 0.0271 ).

The table also reveals that unlike the expectation, franchise value and asset size had a positive correlation before FDICIA, though statistically insignificant. ${ }^{12}$ However, after the FDICIA, these two become more positively correlated ( $\rho$ franchise value, asset from 0.0228 to $0.1629 * *$ ) This is consistent with the hypothesis.

\section{- Overall results of the correlation test -}

Overall, the results in Table 3 indicate that the tendency of the banks toward positive (or, simultaneous) associations of the higher risk characteristic variables (low capital ratio, low franchise value, large asset size, and high $\beta$ ), over the pre-FDICIA period, became weaker and less significant after the FDICIA, indicating that banks seem to have made their operating structures safer than before. Also, the results show that the correlations for the whole sample period (1988-1995) between the four variables are generally consistent with those expected in the literature.

\section{Results of the Test for Systematic Risk-taking Incentives}

The results of the test for how the FDICIA affects the systematic risk-taking incentives of the banks is presented in Table 4 , based on the sign and statistical significance of the coefficient on the FDICIA dummy interaction variables, $b_{11}$, $\mathrm{b}_{21}, \mathrm{~b}_{31}$ and $\mathrm{b}_{41}$.

\section{(1) Intercept Term}

The result in Table 4 shows that the coefficient $b_{01}$ is negative, though it is not significant at the $10 \%$ significance level. This result indicates that the overall systematic risk-taking behavior of banks, given the control variables, shifted downward after the FDICIA.

\section{(2) Moral Hazard Incentives of Stockholders}

The moral-hazard-incentives-of-stockholders hypothesis predicts that the (capital 
ratio) $)_{\mathrm{t}}$ and incremental risk, $\beta_{\mathrm{t}+1-} \beta_{\mathrm{t}}$, would be negatively related. Consistent with this hypothesis, the coefficient on the capital ratio $\left(b_{10}\right)$ is negative. However, it is not statistically significant. Thus, this result does not offer strong support for the existence of the moral hazard incentives of stockholders with respect to the systematic risk-taking measure, before the FDICIA. The reason for this result may be because several other regulations in the late 1980s, such as the Prompt Corrective Actions or Risk-Based Capital Requirement, may have been somewhat effective in discouraging the perverse risk-taking of the banks with low capital ratio.

We hypothesized that, if the FDICIA was effective in reducing the systematic moral hazard incentives of stockholders, the coefficient on the interaction term $D^{*}$ (capital ratio) $)_{t}$ would be positively related to $\beta_{t+1}-\beta_{t}$. Consistent with this hypothesis, the coefficient is significantly positive. After the FDICIA, the tendencies of lower capital-ratio banks to pursue riskier strategies would have been weaker because those activities would result in heavier regulatory oversights and higher costs compared to the pre-FDICIA period.

\section{(3) Franchise value}

The franchise-value hypothesis predicts that the (franchise value) $t$ and incremental risk, $\beta_{\mathrm{t}+1}-\beta_{\mathrm{t}}$, would be negatively related. Consistent with this hypothesis, the coefficient on the franchise value $\left(b_{20}\right)$ is negative - fairly significant at a $15 \%$ significance level. Thus, this result offers some support for the existence of the systematic moral hazard incentives associated with franchise value before the FDICIA.

We hypothesized that, if the FDICIA is effective in reducing the systematic moral hazard incentives associated with the franchise value, the coefficient on the interaction term $D *(\text { franchise value })_{t}$ would be positively related to $\beta_{\mathrm{t}+1}-\beta_{\mathrm{t}}$. Consistent with this hypothesis, the coefficient is significantly positive. After the FDICIA, the tendencies of lower franchise value banks to pursue riskier strategies would be weaker because those activities would result in heavier regulatory oversights and higher costs compared to the pre-FDICIA period.

\section{(4) Firm size}

The "too-big-to-fail-policy" hypothesis predicts that (asset size) $)_{\mathrm{t}}$ and incremental risk, $\beta_{t+1}-\beta_{t}$, would be positively related. Consistent with this hypothesis, the coefficient on the asset size $\left(b_{30}\right)$ is significantly positive. Thus, this result offers strong support for the existence of the systematic moral hazard incentives associated with firm size before the FDICIA.

We hypothesized that, if the FDICIA is effective in reducing the systematic moral hazard incentives associated with firm size, the coefficient on the interaction term $D^{*}$ (asset size) $)_{\mathrm{c}}$ would be negatively related to $\beta_{\mathrm{t}+1}-\beta_{\mathrm{t}}$. Consistent with this hypothesis, the coefficient is significantly negative. After the FDICIA, the tendencies 
of larger banks to pursue riskier strategies would be weaker because those activities would result in heavier regulatory oversights and higher costs compared to the pre-FDICIA period.

\section{(5) Current (Base period's) risk level}

We hypothesized that, after the FDICIA, the relationship between current risk level and subsequent incremental risk would be more negative. Consistent with this hypothesis, the coefficient on the interaction term, $D^{*}\left(\beta_{\mathrm{t}}\right)$ is negative, though insignificant.

\section{TABLE 4.}

This table shows the results for how the FDICIA affects the systematic risk-taking incentives of the banks. The table shows the coefficients and t-statistics. $* * *$ denotes statistical significance at $1 \%$ level, **denotes statistical significance at $5 \%$ level, *denotes statistical significance at $10 \%$ level.

$$
\begin{aligned}
\beta_{\mathrm{i}, \mathrm{t}+1}-\beta_{\mathrm{i}, \mathrm{t}}=\mathrm{b}_{00} & +\mathrm{b}_{01} * \mathrm{D}+\mathrm{b} 10(\text { Capital-to-asset })_{\mathrm{i}, \mathrm{t}}+\mathrm{b}_{11} * \mathrm{D} *(\text { Capital-to-asset })_{\mathrm{i}, \mathrm{t}} \\
& +\mathrm{b}_{20}(\text { Market-book })_{\mathrm{i}, \mathrm{t}}+\mathrm{b}_{21} * \mathrm{D} *(\text { Market-book })_{\mathrm{i}, \mathrm{t}} \\
& +\mathrm{b}_{30}(\text { Asset })_{i, \mathrm{t}}+\mathrm{b}_{31} * \mathrm{D} *(\text { Asset })_{\mathrm{i}, \mathrm{t}} \\
+ & \mathrm{b}_{40}\left(\beta_{\mathrm{i}, \mathrm{t}}\right)+\mathrm{b}_{41} * \mathrm{D} *\left(\beta_{\mathrm{i}, \mathrm{t}}\right)+\mathrm{b}_{\mathrm{s}}(\mathrm{GDP} \text { growth })_{\mathrm{r}}+\varepsilon_{\mathrm{i}, \mathrm{t}} \\
& , \text { where } \mathrm{D}=1 \text { if after FDICIA, and } 0 \text { otherwise }
\end{aligned}
$$

\begin{tabular}{|c|c|c|}
\hline Independent variables & $\begin{array}{l}\text { Predicted sign associated with } \\
\text { the FDICIA }\end{array}$ & \\
\hline Intercept & & $\begin{array}{l}1.0545 * * \\
(2.43)\end{array}$ \\
\hline$D *($ Intercept $)$ & & $\begin{array}{l}-0.6512 \\
(-1.22)\end{array}$ \\
\hline$(\text { Capital-to-asset })_{i, t}$ & & $\begin{array}{l}-4.3753 \\
(-0.99)\end{array}$ \\
\hline $\mathrm{D} *(\text { Capital-to-asset })_{\mathrm{i}, \mathrm{t}}$ & $b_{11}:(+)$ & $\begin{array}{l}11.1962 * \\
(1.64)\end{array}$ \\
\hline$(\text { Market-book })_{i, t}$ & & $\begin{array}{c}-0.0058 \\
(-1.42)\end{array}$ \\
\hline $\mathrm{D} *(\text { Market-book })_{\mathrm{i}, \mathrm{t}}$ & $b_{21}:(+)$ & $\begin{array}{l}0.0124^{*} \\
(1.66)\end{array}$ \\
\hline$(\text { Asset } \text { size })_{i, \mathrm{t}}$ & & $\begin{array}{l}\text { 6.7E-06** } \\
\quad(2.18)\end{array}$ \\
\hline$D^{*}(\text { Asset size })_{i, \mathrm{t}}$ & $b_{31}:(-)$ & $\begin{array}{c}-5.0 \mathrm{E}-06^{*} \\
(-1.63)\end{array}$ \\
\hline$\beta_{\mathrm{i}, \mathrm{t}}$ & & $\begin{array}{l}-0.9623 * * * \\
(-15.65)\end{array}$ \\
\hline $\mathrm{D} *\left(\beta_{\mathrm{i}, \mathrm{t}}\right)$ & $b_{41}:(-)$ & $\begin{array}{l}-0.0362 \\
(-0.47)\end{array}$ \\
\hline$\% \mathrm{GDP}$ & & $\begin{array}{l}-4.6669 \\
(-0.91)\end{array}$ \\
\hline $\begin{array}{l}\text { F-statistics } \\
\text { Adjusted } \mathrm{R}^{2}\end{array}$ & & $69.95^{\mathrm{k} * * *}$ \\
\hline
\end{tabular}


- Overall results of the test for the effect of the FDICIA on banks' systematic risk-taking incentives based on the full sample -

Overall, the results in Table 4 indicate that, before the FDICIA, as the risk characteristics of the banks were higher, their systematic incremental risk factors were greater. This was particularly so with respect to the firm size and franchise value. This result would imply that systematic moral hazard incentive problems with respect to these variables seems to have existed for the full sample banks used in the research. However, as reflected in the signs and significance levels of the $D^{*}()$, those incentives were significantly decreased after the FDICIA, with respect to all the three risk characteristic variables. Thus, we conclude that the FDICIA seems to be effective in reducing the systematic moral hazard incentives of the banks. Although the sample size is small compared to the population of banks and bank holding companies in the industry, the total assets of the sample banks accounted for an average of $37 \%$ of the total assets of the approximately 14,000 insured banks during the sample period.

\section{Results of the Test for Nonsystematic Risk-taking Incentives}

The results of the test which indicate how the FDICIA affects the nonsystematic risk-taking incentives of the banks are presented in Table 5 and 6 .

Overall, the results in tables show that, with the FDICIA, the signs of the change in the banks' nonsystematic risk-taking incentives are generally consistent with the hypotheses. However, most of the changes are statistically insignificant. Consistent with the hypothesis, the coefficient on the $\mathrm{D}^{*}$ (capital ratio) is positive with respect to both $\sigma_{\mathrm{i}, \mathrm{t}+1}-\sigma_{\mathrm{i}, \mathrm{t}}$ and $\sigma^{2}\left(\varepsilon_{\mathrm{i}, \mathrm{t}+1}\right)-\sigma^{2}\left(\varepsilon_{\mathrm{i}, \mathrm{t}}\right)$; significantly positive with respect to $\sigma_{\mathrm{i}, \mathrm{t}+1}-\sigma_{\mathrm{i}, \mathrm{t}}$ and insignificantly positive with respect to $\sigma^{2}\left(\varepsilon_{\mathrm{i}, \mathrm{t}+1}\right)-\sigma^{2}\left(\varepsilon_{\mathrm{i}, \mathrm{t}}\right)$. Consistent with the hypothesis, the coefficient on the $\mathrm{D} *$ (franchise value $)_{t}$ is positive with respect to both $\sigma_{\mathrm{i}, \mathrm{t}+1}-\sigma_{\mathrm{i}, \mathrm{t}}$ and $\sigma^{2}\left(\varepsilon_{\mathrm{i}, \mathrm{t}+1}\right)-\sigma^{2}\left(\varepsilon_{\mathrm{i}, \mathrm{t}}\right)$. However, none of them are statistically significant at the $10 \%$ significance level. Consistent with the hypothesis, the coefficient on the $\mathrm{D} *$ (current risk level $)_{t}$ is negative with respect to both $\sigma_{i, t+1}-\sigma_{i, t}$ and $\sigma^{2}\left(\varepsilon_{i, t+1}\right)-\sigma^{2}\left(\varepsilon_{i, t}\right)$. However, none of them are significant. Inconsistent with the hypothesis, the positive coefficients on the $\mathrm{D}^{*}(\text { asset size })_{\mathrm{t}}$ indicate that the moral hazard incentives associated with firm size, with respect to the nonsystematic risk-taking measures, did not decrease at all after the FDICIA. Indeed, they appear to have increased. This result might indicate that even though larger banks decrease their firm-size-related systematic risk-taking incentives after the FDICIA (as is presented in 4.3), they appear to use their better diversification advantage (across projects, and hence better asset quality and more advantageous position at the assessment of the bank's overall risk factor by the regulator) under the FDICIA in not decreasing their nonsystematic risk-taking incentives.

The above findings, that the change in the nonsystematic risk-taking incentives 
of the banks is insignificant and that firm sizes are not decreased at all, might imply that bankers do not assume that nonsystematic risks of the bank would be carefully examined by the regulator as one of the measures of the bank's general risk status, and hence, that the bank's risk-taking incentives with respect to these measures have not been greatly affected after the FDICIA (or, at least, compared to the change in the systematic risk-taking incentives).

\section{TABLE 5.}

This table shows how the FDICIA affects the risk-taking incentives of the banks, using the change in standard deviation of stock returns as the dependent variable.

$$
\begin{aligned}
\sigma_{i, t+1}-\sigma_{i, t}=b_{00} & +b_{01} * \mathrm{D}+b_{10}(\text { Capital-to-asset })_{i, \mathrm{t}}+\mathrm{b}_{11} * \mathrm{D} *(\text { Capital-to-asset })_{i, \mathrm{t}} \\
& +\mathrm{b}_{20}(\text { Market-book })_{\mathrm{i}, \mathrm{t}}+\mathrm{b}_{21} * \mathrm{D} *(\text { Market-book })_{i, \mathrm{t}} \\
& +\mathrm{b}_{30}\left(\text { Asset }_{\mathrm{i}, \mathrm{t}}+\mathrm{b}_{31} * \mathrm{D} *(\text { Asset })_{i, \mathrm{t}}\right. \\
& +\mathrm{b}_{40}\left(\sigma_{\mathrm{i}, \mathrm{t}}\right)+\mathrm{b}_{41} * \mathrm{D} *\left(\sigma_{\mathrm{i}, \mathrm{t}}\right)+\mathrm{b}_{5}(\text { GDP growth })_{\mathrm{t}}+\varepsilon_{\mathrm{i}, \mathrm{t}} \\
& \text {,where } \mathrm{D}=1 \text { if after FDICIA, and } 0 \text { otherwise }
\end{aligned}
$$

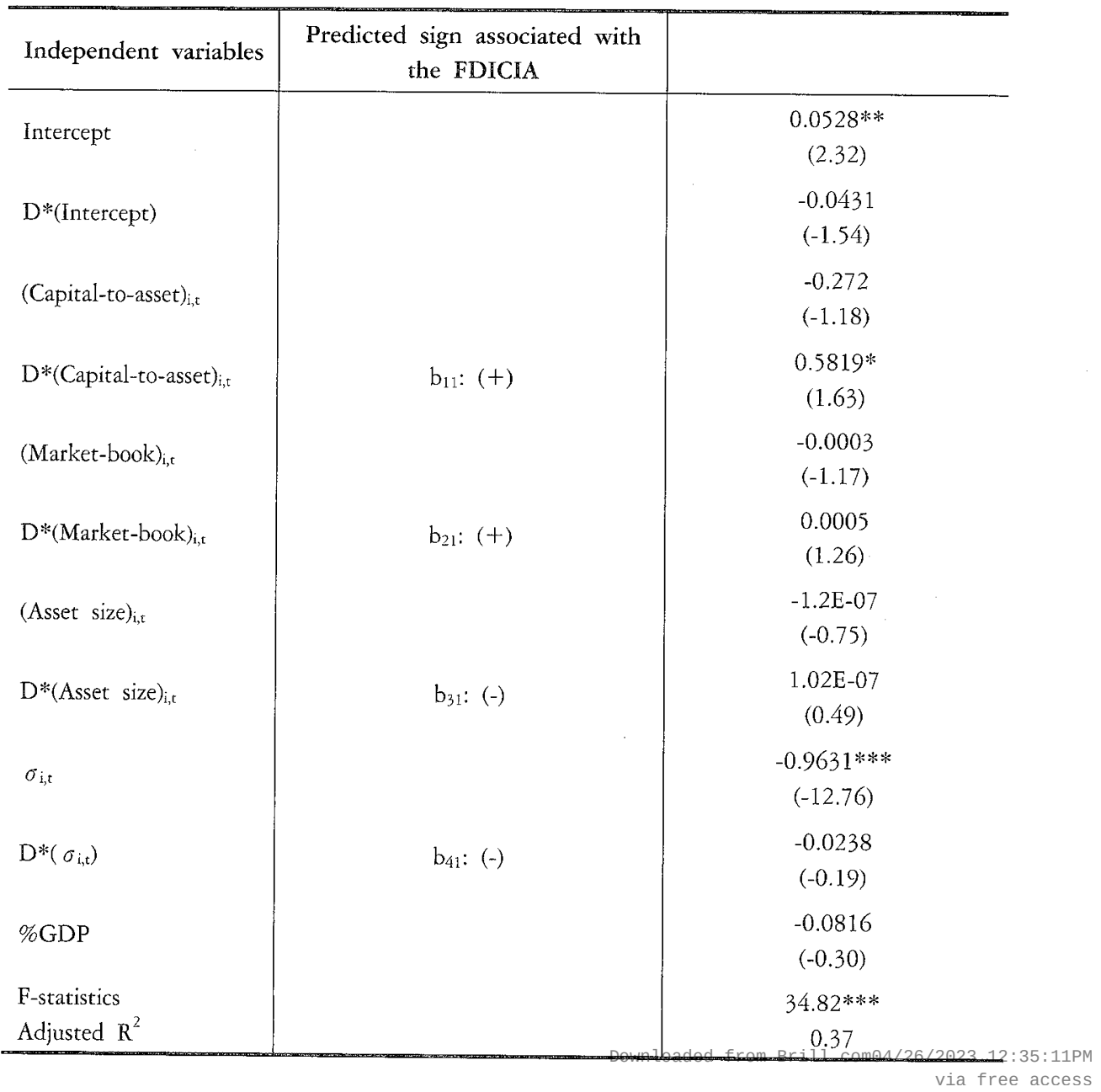




\section{TABLE 6.}

This table shows how the FDICIA affects the risk-taking incentives of the banks, using the residual variance of stock returns as the dependent variable.

$$
\begin{aligned}
\sigma^{2}\left(\varepsilon_{\mathrm{i}, \mathrm{t}+1}\right)-\sigma^{2}\left(\varepsilon_{\mathrm{i}, \mathrm{t}}\right)=\mathrm{b}_{00} & +\mathrm{b}_{01} * \mathrm{D}+\mathrm{b}_{10}(\text { Capital-to-asset })_{\mathrm{i}, \mathrm{t}}+\mathrm{b}_{11} * \mathrm{D} *(\text { Capital-to-asset })_{\mathrm{i}, \mathrm{t}} \\
& +\mathrm{b}_{20}(\text { Market-book })_{\mathrm{i}, \mathrm{t}}+\mathrm{b}_{21} * \mathrm{D} *(\text { Market-book })_{\mathrm{i}, \mathrm{t}} \\
& +\mathrm{b}_{30}(\text { Asset })_{\mathrm{i}, \mathrm{t}}+\mathrm{b}_{31} * \mathrm{D} *(\text { Asset })_{\mathrm{i}, \mathrm{t}} \\
& +\mathrm{b}_{40}\left(\sigma^{2}\left(\varepsilon_{\mathrm{i}, \mathrm{t}}\right)\right)+\mathrm{b}_{41} * \mathrm{D} *\left(\sigma^{2}\left(\varepsilon_{\mathrm{i}, \mathrm{t}}\right)\right)+\mathrm{b}_{\mathrm{s}}(\mathrm{GDP} \text { growth })_{\mathrm{r}}+\varepsilon_{\mathrm{i}, \mathrm{t}} \\
& \text {,where } \mathrm{D}=1 \text { if after the FDICIA, and } 0 \text { otherwise }
\end{aligned}
$$

\begin{tabular}{|c|c|c|}
\hline Independent variables & $\begin{array}{l}\text { Predicted sign associated with } \\
\text { the FDICIA }\end{array}$ & \\
\hline Intercept & & $\begin{array}{c}0.0072 \\
(0.29)\end{array}$ \\
\hline$D *($ Intercept $)$ & & $\begin{array}{c}-0.0188 \\
(-0.60)\end{array}$ \\
\hline$(\text { Capital-to-asset })_{i, t}$ & & $\begin{array}{r}-0.0357 \\
(-0.14)\end{array}$ \\
\hline $\mathrm{D}^{*}$ (Capital-to-asset $)_{i, t}$ & $b_{11}:(+)$ & $\begin{array}{c}0.3659 \\
(0.91)\end{array}$ \\
\hline$(\text { Market-book })_{\mathrm{i}, \mathrm{r}}$ & & $\begin{array}{l}-1.4 \mathrm{E}-05 \\
(-0.06)\end{array}$ \\
\hline $\mathrm{D} *(\text { Market-book })_{i, t}$ & $b_{21}:(+)$ & $\begin{array}{c}0.0004 \\
(1.01)\end{array}$ \\
\hline$\left(\right.$ Asset size $_{i, t}$ & & $\begin{array}{c}-1.7 \mathrm{E}-08 \\
(-0.1)\end{array}$ \\
\hline $\mathrm{D}^{*}(\text { Asset size })_{\mathrm{i}, \mathrm{t}}$ & $b_{31}:(-)$ & $\begin{array}{l}2.13 \mathrm{E}-08 \\
(0.09)\end{array}$ \\
\hline$\sigma^{2}\left(\varepsilon_{\mathrm{i}, \mathrm{t}}\right)$ & & $\begin{array}{c}-0.9989 * * * \\
(-12.13)\end{array}$ \\
\hline $\mathrm{D}^{*}\left(\sigma^{2}\left(\varepsilon_{\mathrm{i}, \mathrm{t}}\right)\right)$ & $\mathrm{b}_{41}:(-)$ & $\begin{array}{l}-0.0245 \\
(-0.22)\end{array}$ \\
\hline$\% \mathrm{GDP}$ & & $\begin{array}{c}-0.0622 \\
(-0.20)\end{array}$ \\
\hline $\begin{array}{l}\text { F-statistics } \\
\text { Adjusted } \mathrm{R}^{2}\end{array}$ & & $\begin{array}{l}34.04 * * * \\
0.37\end{array}$ \\
\hline
\end{tabular}

\section{Stability Test for the Change in Risk-taking Incentives}

In the previous sections' $(4.3 \& 4.4)$ empirical results, we have seen that the FDICIA seems to be effective in reducing the risk-taking incentives of the banks, in particular their systematic risk-taking incentives. To examine whether this decrease (or, change) in the incentives is stable over the post-FDICIA period, 1992-1995, we estimate the equation (4) including two post- FDICIA year dummy interaction variables for each independent variable: $\mathrm{D}_{1}=1$ for 1992 or $1993, \mathrm{D}_{2}=1$ for 1994 or 1995 and 0 otherwise. 13 


\section{TABLe 7.}

This table shows the results for the stability test for the change in the systematic risk-taking incentives of the banks, after the FDICIA.

$$
\begin{aligned}
\left(\beta_{\mathrm{i}, \mathrm{t}+1}-\beta_{\mathrm{i}, \mathrm{t}}\right)= & \mathrm{b}_{00}+\mathrm{b}_{01} * \mathrm{D}_{1}+\mathrm{b}_{02} * \mathrm{D}_{2} \\
& \left.+\mathrm{b}_{10}(\text { Capital-to-asset })_{\mathrm{i}, \mathrm{t}}+\mathrm{b}_{11} * \mathrm{D}_{1} *(\text { Capital-to-asset })_{\mathrm{i}, \mathrm{t}}+\mathrm{b}_{12} * \mathrm{D}_{2} * \text { (Capital-to-asset }\right)_{\mathrm{i}, \mathrm{t}} \\
& +\mathrm{b}_{20}(\text { Market-book })_{\mathrm{i}, \mathrm{t}}+\mathrm{b}_{21} * \mathrm{D}_{1} *(\text { Market-book })_{\mathrm{i}, \mathrm{t}}+\mathrm{b}_{22} * \mathrm{D}_{2} *(\text { Market-book })_{\mathrm{i}, \mathrm{t}} \\
& +\mathrm{b}_{30}\left(\beta_{\mathrm{i}, \mathrm{t}}\right)+\mathrm{b}_{31} * \mathrm{D}_{1} *\left(\beta_{\mathrm{i}, \mathrm{t}}\right)+\mathrm{b}_{32} * \mathrm{D}_{2} *\left(\beta_{\mathrm{i}, \mathrm{t}}\right) \\
& \left.+\mathrm{b}_{40}(\text { Asset })_{\mathrm{i}, \mathrm{t}}+\mathrm{b}_{41} * \mathrm{D}_{1} *(\text { Asset })_{\mathrm{i}, \mathrm{t}}+\mathrm{b}_{42} * \mathrm{D}_{2} *(\text { Asset })_{\mathrm{i}, \mathrm{t}}+\mathrm{b}_{5} \text { (GDP growth }\right)_{\mathrm{t}}+\varepsilon_{\mathrm{i}, \mathrm{t}} \\
& \text {,where } \mathrm{D}_{1}=1 \text { if } 1992 \text { or } 1993 \text {, and } 0 \text { otherwise, } \mathrm{D}_{2}=1 \text { if } 1994 \text { or } 1995 \text {, and } 0 \text { otherwise }
\end{aligned}
$$

\begin{tabular}{|c|c|}
\hline Independent variables] & \\
\hline Intercept & $\begin{array}{c}1.0542 * * \\
(2.43)\end{array}$ \\
\hline $\mathrm{D}_{1} *$ (Intercept $)$ & $\begin{array}{c}-0.1777 \\
(-0.22)\end{array}$ \\
\hline $\mathrm{D}_{2} *$ (Intercept) & $\begin{array}{c}-1.0752 * \\
(-1.73)\end{array}$ \\
\hline$(\text { Capital-to-asset })_{\mathrm{i}, \mathrm{t}}$ & $\begin{array}{c}-4.3751 \\
(-0.99)\end{array}$ \\
\hline $\mathrm{D}_{1} *(\text { Capital-to-asset })_{\mathrm{i}, \mathrm{t}}$ & $\begin{array}{c}5.1156 \\
(0.49)\end{array}$ \\
\hline $\mathrm{D}_{2} *(\text { Capital-to-asset })_{i, \mathrm{t}}$ & $\begin{array}{c}15.7294 * * \\
(2.02)\end{array}$ \\
\hline$(\text { Market-book })_{i, t}$ & $\begin{array}{c}-0.0058 \\
(-1.42)\end{array}$ \\
\hline $\mathrm{D}_{1} *(\text { Market-book })_{\mathrm{i}, \mathrm{t}}$ & $\begin{array}{l}0.0036 \\
(0.31)\end{array}$ \\
\hline $\mathrm{D}_{2} *(\text { Market-book })_{\mathrm{i}, \mathrm{t}}$ & $\begin{array}{l}0.0182 * * \\
(2.10)\end{array}$ \\
\hline$\beta_{\mathrm{i}, \mathrm{t}}$ & $\begin{array}{c}-0.9623 * * * \\
(-15.64)\end{array}$ \\
\hline $\mathrm{D}_{1} *\left(\beta_{\mathrm{i}, \mathrm{t}}\right)$ & $\begin{array}{c}0.1701 \\
(0.66)\end{array}$ \\
\hline $\mathrm{D}_{2} *\left(\beta_{\mathrm{i}, \mathrm{t}}\right)$ & $\begin{array}{c}-0.0518 \\
(-0.66)\end{array}$ \\
\hline$\left(\right.$ Asset size $_{\mathrm{i}, \mathrm{t}}$ & $\begin{array}{l}6.65 \mathrm{E}-06^{* * *} \\
(2.18)\end{array}$ \\
\hline $\mathrm{D}_{1} *(\text { Asset size })_{\mathrm{i}, \mathrm{c}}$ & $\begin{array}{c}-3.5 \mathrm{E}-06 \\
(-0.57)\end{array}$ \\
\hline $\mathrm{D}_{2} *(\text { Asset size })_{\mathrm{i}, \mathrm{t}}$ & $\begin{array}{c}-5.7 \mathrm{E}-06 \\
(-1.31)\end{array}$ \\
\hline$\% \mathrm{GDP}$ & $\begin{array}{c}-4.6610 \\
(-0.90)\end{array}$ \\
\hline $\begin{array}{l}\text { F-statistics } \\
\text { Adjusted } \mathrm{R}^{2}\end{array}$ & $\begin{array}{c}46.88 * * * * \\
0.55\end{array}$ \\
\hline
\end{tabular}

$$
\begin{aligned}
& \beta_{\mathrm{i}, \mathrm{t}+1-\beta_{\mathrm{i}, \mathrm{t}}}=\mathrm{b}_{00}+\mathrm{b}_{01} * \mathrm{D}_{1}+\mathrm{b}_{02} * \mathrm{D}_{2} \\
& +b_{10}(\text { Capital-to-asset })_{i, \mathrm{t}}+\mathrm{b}_{11} * \mathrm{D}_{1} *(\text { Capital-to-asset })_{\mathrm{i}, \mathrm{t}}+\mathrm{b}_{12} * \mathrm{D}_{2} *(\text { Capital-to-asset })_{\mathrm{i}, \mathrm{t}} \\
& +\mathrm{b}_{20}(\text { Market-book })_{\mathrm{i}, \mathrm{t}}+\mathrm{b}_{21} * \mathrm{D}_{1} *(\text { Market-book })_{\mathrm{i}, \mathrm{t}}+\mathrm{b}_{22} * \mathrm{D}_{2} *(\text { Market-book })_{\mathrm{i}, \mathrm{t}} \\
& +\mathrm{b}_{30}\left(\beta_{\mathrm{i}, \mathrm{t}}\right)+\mathrm{b}_{31} * \mathrm{D}_{1} *\left(\beta_{\mathrm{i}, \mathrm{t}}\right)+\mathrm{b}_{31} * \mathrm{D}_{2} *\left(\beta_{\mathrm{i}, \mathrm{t}}\right) \\
& +b_{40}\left(\text { Asset }_{i, t}+b_{41} * D_{1} *\left(\text { Asset }_{i, \mathrm{t}}+\mathrm{b}_{41} * \mathrm{D}_{1} *(\text { Asset })_{\mathrm{it}}+\mathrm{b}_{5}(\mathrm{GDP} \text { growth })_{\mathrm{t}}+\varepsilon_{\mathrm{B}}\right.\right.
\end{aligned}
$$


The estimation equation with respect to the nonsystematic incremental risk measures $\left(\Delta \sigma, \Delta \sigma^{2}(\varepsilon)\right)$ are similarly specified.

Table 7 presents the result of this test with respect to the banks' systematic risk-taking incentives $(\Delta \beta)$. As the result in table shows, all the signs of the coefficients on the 1994-1995 dummy interaction variables, $\mathrm{D}_{2} *()$, are the same as the hypotheses and they are more significant than the coefficients on the 1992-1993 dummy interaction variables, $D_{1} *()$. Furthermore, in the cases of the same sign, the absolute values of the coefficients on $\mathrm{D}_{2} *()$ are greater than those on $\mathrm{D}_{1} *()$, indicating that the amount of the decrease in the incentives was greater in 1994-1995 period than in the 1992-1993 period: The coefficient on $\mathrm{D}_{2} *$ (intercept) are significantly negative. The coefficient on $\mathrm{D}_{2} *$ (capital ratio) is significantly positive. The coefficient on $\mathrm{D}_{2} *$ (market-book) is significantly positive. The coefficient on $\mathrm{D}_{2} *$ (asset size) is more significantly negative than that on $\mathrm{D}_{1} *$ (asset size). The coefficient on $\mathrm{D}_{2} *(\beta)$ is negative, while that on $\mathrm{D}_{1} *(\beta)$ is positive. These empirical findings are similarly observed with respect to the change in the banks' nonsystematic risk-taking incentives $\left(\Delta \sigma, \Delta \sigma^{2}(\varepsilon)\right) .{ }^{14}$ In this research, 1992 was the first event year after the FDICIA. Thus, these results may indicate that the decrease in the risk-taking incentives became more significant and greater as the FDICIA system was established more and more firmly.

\section{Empirical Results Based on the Partitioned Sample}

In this section, we examine how the FDICIA differently affects the risk-taking incentives of the banks, ${ }^{15}$ dividing the full sample into two groups. Following the implications of the literature, we partition the full sample into two groups: banks with higher moral hazard incentives as those with larger asset sizes and lower capital-to-asset ratios, banks with lower moral hazard incentives as those with smaller asset sizes and higher capital-to-asset ratios. Each year, larger/smaller asset size is partitioned on the basis of the median for all banks for asset-size variable in our sample. Lower/higher capital ratio is similarly defined.

First, to examine how the systematic risk-taking incentives of the larger and smaller banks were different before the FDICIA, we estimate the following equation (5) for 1988-1991 period.

$$
\begin{aligned}
\beta_{\mathrm{i}, \mathrm{t}+1}-\beta_{\mathrm{i}, \mathrm{t}}=\mathrm{b}_{0} & +\mathrm{b}_{10}(\text { Capital-to-asset })_{\mathrm{i}, \mathrm{t}}+\mathrm{b}_{11} * \mathrm{D} *(\text { Capital-to-asset })_{\mathrm{i}, \mathrm{t}} \\
& +\mathrm{b}_{20}(\text { Market-book })_{\mathrm{i}, \mathrm{t}}+\mathrm{b}_{21} * \mathrm{D} *(\text { Market-book })_{\mathrm{i}, \mathrm{t}} \\
& +\mathrm{b}_{30}(\text { Asset })_{\mathrm{i}, \mathrm{t}}+\mathrm{b}_{31} * \mathrm{D} *(\text { Asset })_{\mathrm{i}, \mathrm{t}} \\
& +\mathrm{b}_{40}\left(\beta_{\mathrm{i}, \mathrm{t}}\right)+\mathrm{b}_{41} * \mathrm{D} *\left(\beta_{\mathrm{i}, \mathrm{t}}\right)+\mathrm{b}_{5}(\text { GDP growth })_{\mathrm{t}}+\varepsilon_{\mathrm{i}, \mathrm{t}}
\end{aligned}
$$

, where $\mathrm{D}=1$ if the bank belongs to the larger asset-size group and 0 otherwise.

According to the above equation, the coefficient on $D^{*}($ ) indicates how the 
risk-taking incentives of the larger banks are different from those of the smaller banks before the FDICIA.

Next, how the FDICIA differently affects the systematic risk-taking incentives of the larger banks from those of the smaller banks is examined by estimating the following equation (6):

$$
\begin{aligned}
\beta_{\mathrm{i}, \mathrm{t}+1}-\beta_{\mathrm{i}, \mathrm{t}}=\mathrm{b}_{0}+ & \mathrm{b}_{10}(\text { Capital-to-asset })_{\mathrm{i}, \mathrm{t}}+\mathrm{b}_{11} * \mathrm{D}_{1} *(\text { Capital-asset })_{\mathrm{i}, \mathrm{t}} \\
& +\mathrm{b}_{12} * \mathrm{D}_{1} * \mathrm{D}_{2} *(\text { Capital-asset })_{\mathrm{i}, \mathrm{t}} \\
+ & \mathrm{b}_{20}(\text { Market-book })_{\mathrm{i}, \mathrm{t}}+\mathrm{b}_{21} * \mathrm{D}_{1} *(\text { Market-book })_{\mathrm{i}, \mathrm{t}} \\
& +\mathrm{b}_{22} * \mathrm{D}_{1} * \mathrm{D}_{2} *(\text { Market-book })_{\mathrm{i}, \mathrm{t}} \\
+ & \mathrm{b}_{30}\left(\beta_{\mathrm{i}, \mathrm{t}}\right)+\mathrm{b}_{31} * \mathrm{D}_{1} *\left(\beta_{\mathrm{i}, \mathrm{t}}+\mathrm{b}_{31} * \mathrm{D}_{1} * \mathrm{D}_{2} *\left(\beta_{\mathrm{i}, \mathrm{t}}\right)\right. \\
+ & \mathrm{b}_{40}(\text { Asset })_{\mathrm{i}, \mathrm{t}}+\mathrm{b}_{41} * \mathrm{D}_{1} *(\text { Asset })_{\mathrm{i}, \mathrm{t}}+\mathrm{b}_{41} * \mathrm{D}_{1} * \mathrm{D}_{2} *(\text { Asset })_{\mathrm{i}, \mathrm{t}} \\
& +\mathrm{b}_{5}(\text { GDP growth })_{\mathrm{t}}+\varepsilon \mathrm{\varepsilon} \text { g }
\end{aligned}
$$

, where $D_{1}=1$ if after the FDICIA and 0 otherwise, $D_{2}=1$ if larger asset-size bank and 0 otherwise

According to the above equation, the coefficients on the $\mathrm{D}_{1} * \mathrm{D}_{2} *($ ) represent how the change in the larger banks' systematic risk-taking incentives is different from that of the smaller banks after the FDICIA.

The estimation equation for the lower/higher capital ratio banks is similarly specified. Also, the estimation equations with respect to the nonsystematic incremental risk measures $\left(\Delta \sigma, \Delta \sigma^{2}(\varepsilon)\right)$ are similarly specified.

\section{(1) Before the FDICIA}

Table 8 (9) presents how the larger banks' systematic (nonsystematic) risk-taking incentives were different from those of the smaller banks before the FDICIA.

As the result in Table 8 shows, the difference in the systematic risk-taking incentives between larger and smaller banks was mixed before the FDICIA: The coefficient on the $\mathrm{D} *$ (market-book) is significantly negative and that on the $\mathrm{D}^{*}(\beta)$ is significantly positive. This indicates that, with respect to these variables, larger banks' incentives are significantly greater than those of the smaller banks. However, as the coefficient on the $\mathrm{D}$ *(capital ratio) is significantly positive and the coefficient on the $\mathrm{D}^{*}$ (asset size) is significantly negative, it appears that, with respect to these variables, smaller banks' incentives are significantly greater than those of the larger banks.

However, the result in Table 9 shows that the nonsystematic risk-taking incentives of the larger banks were greater than those of the smaller banks before the FDICIA, with respect to both $\Delta \sigma$ and $\Delta \sigma^{2}(\varepsilon)$, for all the four independent variables: The coefficient on the $\mathrm{D}^{*}$ (capital ratio) is significantly negative. The coefficient on the $D^{*}$ (asset size) is significantly positive. The coefficient on the $D^{*}$ (franchise value) 
is negative, though insignificant. The coefficients on the $\mathrm{D} *\left(\sigma_{\mathrm{i}, \mathrm{t}}\right)$ and $\mathrm{D} *\left(\sigma^{2}\left(\varepsilon_{\mathrm{i}, \mathrm{t}}\right)\right)$ are positive, though insignificant. These empirical findings are similarly (or better) observed for the lower/higher capital ratio banks.

Thus, even though the difference of systematic risk-taking incentives between the higher moral hazard incentive banks' (larger and lower capital ratio banks) and the lower moral hazard incentive banks (smaller and higher capital ratio banks) was mixed before the FDICIA, their nonsystematic incentives were greater than those of the lower moral hazard incentive banks. This result may indicate higher moral hazard incentive banks' discretionary risk-taking behavior being reflected in the nonsystematic incremental risk measures rather than the systematic one.

\section{TABLe 8.}

This table shows how the systematic risk-taking incentives are different between larger and smaller banks, before the FDICIA.

$$
\begin{aligned}
& \beta_{\mathrm{i}, \mathrm{t}+1}-\beta_{\mathrm{i}, \mathrm{t}}=\mathrm{b}_{0}+\mathrm{b}_{10}(\text { Capital-to-asset })_{\mathrm{i}, \mathrm{t}}+\mathrm{b}_{11} * \mathrm{D} *(\text { Capital-to-asset })_{\mathrm{i}, \mathrm{t}} \\
& +b_{20}(\text { Market-book })_{i, t}+b_{21} * \mathrm{D} *(\text { Market-book })_{i, t} \\
& +b_{30}\left(\beta_{i, t}\right)+b_{31} * \mathrm{D} *\left(\beta_{\mathrm{i}, t}\right) \\
& +b_{40}(\text { Asset })_{i, t}+b_{41} * D *(\text { Asset })_{i, t}+b_{5}(\text { GDP growth })_{t}+\varepsilon_{i, c} \\
& \text {, where } D=1 \text { if larger asset size group's bank, and } 0 \text { otherwise }
\end{aligned}
$$

\begin{tabular}{|c|c|}
\hline Independent variables & \\
\hline Intercept & $\begin{array}{c}0.7618 * * * * \\
(3.91)\end{array}$ \\
\hline (Capital-to-asset $)_{i, \tau}$ & $\begin{array}{c}-3.2814 * * \\
(1.92)\end{array}$ \\
\hline $\mathrm{D} *(\text { Capital-to-asset })_{\mathrm{i}, \mathrm{t}}$ & $\begin{array}{c}7.7080^{* * * *} \\
(4.45)\end{array}$ \\
\hline$(\text { Market-book })_{\mathrm{i}, t}$ & $\begin{array}{c}-0.0014 \\
(-0.51)\end{array}$ \\
\hline$D^{*}(\text { Market-book })_{i, \mathrm{r}}$ & $\begin{array}{c}-0.0073^{* * *} \\
(-2.17)\end{array}$ \\
\hline$\beta_{\mathrm{i}, \mathrm{t}}$ & $\begin{array}{c}-0.9971 * * * \\
(-40.64)\end{array}$ \\
\hline $\mathrm{D} *\left(\beta_{\mathrm{i}, \mathrm{t}}\right)$ & $\begin{array}{c}0.2272 * * * \\
(2.79)\end{array}$ \\
\hline$\left(\right.$ Asset size $_{\mathrm{i}, \mathrm{t}}$ & $\begin{array}{c}5.83 \mathrm{E}-05^{* * * *} \\
(2.76)\end{array}$ \\
\hline $\mathrm{D} *(\text { Asset } \text { size })_{\mathrm{i}, \mathrm{t}}$ & $\begin{array}{c}-5.5 \mathrm{E}-05^{*} * * * \\
(-2.61)\end{array}$ \\
\hline$\% G D P$ & $\begin{array}{c}-6.44 * * * \\
(-2.98)\end{array}$ \\
\hline $\begin{array}{l}\text { F-statistics } \\
\text { Adjusted } R^{2}\end{array}$ & $\begin{array}{c}198.84 * * * \\
0.84\end{array}$ \\
\hline
\end{tabular}




\section{TABLE 9.}

This table shows how the nonsystematic risk-taking incentives are different between larger and smaller banks, before the FDICIA.

$$
\begin{aligned}
\sigma_{\mathrm{i}, \mathrm{t}+1}-\sigma_{\mathrm{i}, \mathrm{t}}\{ & \text { or, } \left.\left.\left.\sigma^{2}\left(\varepsilon_{\mathrm{i}, \mathrm{t}+1}\right)-\sigma^{2}\left(\varepsilon_{\mathrm{i}, \mathrm{t}}\right)\right\}=\mathrm{b}_{0}+\mathrm{b}_{10} \text { (Capital-to-asset }\right)_{\mathrm{i}, \mathrm{t}}+\mathrm{b}_{11} * \mathrm{D} * \text { (Capital-to-asset }\right)_{\mathrm{i}, \mathrm{t}} \\
& +\mathrm{b}_{20}(\text { Market-book })_{\mathrm{i}, \mathrm{t}}+\mathrm{b}_{21} * \mathrm{D} *(\text { Market-book })_{\mathrm{i}, \mathrm{t}} \\
& +\mathrm{b}_{30}\left(\sigma_{\mathrm{i}, \mathrm{t}}\right)+\mathrm{b}_{31} * \mathrm{D} *\left(\sigma_{\mathrm{i}, \mathrm{t}}\right) \text { (or, } \mathrm{b}_{30} \sigma^{2}\left(\varepsilon_{\mathrm{i}, \mathrm{t}}+\mathrm{b}_{31} * \mathrm{D}^{*} \sigma^{2}\left(\varepsilon_{\mathrm{i}, \mathrm{t}}\right)\right\} \\
& +\mathrm{b}_{40}(\text { Asset })_{\mathrm{i}, \mathrm{t}}+\mathrm{b}_{41} * \mathrm{D} *(\text { Asset })_{\mathrm{i}, \mathrm{t}}+\mathrm{b}_{\mathrm{s}}(\mathrm{GDP} \text { growth })_{\mathrm{t}}+\varepsilon_{\mathrm{i}, \mathrm{t}} \\
& \text {,where } \mathrm{D}=1 \text { if larger asset size group's bank, and } 0 \text { otherwise }
\end{aligned}
$$

\begin{tabular}{|c|c|c|}
\hline Independent variables & Dependent $=\sigma_{\mathrm{i}, \mathrm{t}+1}-\sigma_{\mathrm{i}, \mathrm{t}}$ & Dependent $=\sigma^{2}\left(\varepsilon_{\mathrm{i}, t+1}\right)-\sigma^{2}\left(\varepsilon_{\mathrm{i}, \mathrm{t}}\right)$ \\
\hline Intercept & $\begin{array}{c}0.0699 * * \\
(11.85)\end{array}$ & $\begin{array}{c}0.0053^{* * *} \\
(8.63)\end{array}$ \\
\hline$(\text { Capital-to-asset })_{i, t}$ & $\begin{array}{c}-0.3179 * * * \\
\quad(-6.58)\end{array}$ & $\begin{array}{c}-0.0383 * * * * \\
(-6.89)\end{array}$ \\
\hline$D^{*}(\text { Capital-to-asset })_{i, t}$ & $\begin{array}{c}-0.2803 * * * * \\
(-5.54)\end{array}$ & $\begin{array}{c}-0.0383 * * * \\
(-6.88)\end{array}$ \\
\hline$(\text { Market-book })_{i, t}$ & $\begin{array}{c}-0.0002 * * \\
(-2.07)\end{array}$ & $\begin{array}{c}-9.7 \mathrm{E}-06 \\
(-1.1)\end{array}$ \\
\hline $\mathrm{D} *(\text { Market-book })_{i, t}$ & $\begin{array}{c}-7.1 \mathrm{E}-05 \\
(-0.75)\end{array}$ & $\begin{array}{c}-8.5 \mathrm{E}-05 \\
(-0.78)\end{array}$ \\
\hline$\sigma_{\mathrm{i}, \mathrm{t}}$ & $\begin{array}{c}-0.9771 * * * * \\
(-64.05)\end{array}$ & \\
\hline $\mathrm{D} *\left(\sigma_{\mathrm{i}, \mathrm{t}}\right)$ & $\begin{array}{l}0.0279 \\
(0.31)\end{array}$ & \\
\hline$\sigma^{2}\left(\varepsilon_{\mathrm{i}, \mathrm{t}}\right)$ & & $\begin{array}{c}-1.0003 * * * \\
(-583.4)\end{array}$ \\
\hline $\mathrm{D} *\left(\sigma^{2}\left(\varepsilon_{\mathrm{i}, \mathrm{t}}\right)\right)$ & & $\begin{array}{l}0.0209 \\
(0.18)\end{array}$ \\
\hline$(\text { Asset size })_{i, t}$ & $\begin{array}{c}-3.6 \mathrm{E}-06 * * * \\
(-6.13)\end{array}$ & $\begin{array}{c}-3.7 \mathrm{E}-07 * * * \\
(-5.37)\end{array}$ \\
\hline$D *(\text { Asset size })_{i, t}$ & $\begin{array}{c}3.5 \mathrm{E}-07 * * * \\
(5.99)\end{array}$ & $\begin{array}{c}3.54 \mathrm{E}-07 * * * \\
(5.21)\end{array}$ \\
\hline$\% \mathrm{GDP}$ & $\begin{array}{l}-0.0598 \\
(-1.01)\end{array}$ & $\begin{array}{l}-0.0024 \\
(-0.36)\end{array}$ \\
\hline $\begin{array}{l}\text { F-statistics } \\
\text { Adjusted } \mathrm{R}^{2}\end{array}$ & $\begin{array}{c}464.36 * * * * \\
0.93 \\
\end{array}$ & $\begin{array}{c}383.31 * * * * \\
0.98\end{array}$ \\
\hline
\end{tabular}

\section{(2) After the FDICIA}

Table 10 (11) indicates how the responses of the larger banks' systematic risk-taking incentives to the FDICIA are different from those of the smaller banks.

The results in table 10 show that, after the FDICIA, the decrease in the systematic risk-taking incentives of the larger banks is a little less than that of the smaller banks. The coefficient on the $\mathrm{D}_{1} * \mathrm{D}_{2} *$ (franchise value) is significantly negative. The coefficient on the $\mathrm{D}_{1} * \mathrm{D}_{2} *$ (capital ratio) is insignificantly negative. The coefficient on the $\mathrm{D}_{1} * \mathrm{D}_{2} *(\beta)$ is insignificantly positive. The coefficient on the $\mathrm{D}_{1} * \mathrm{D}_{2} *$ (asset 
size) is insignificantly positive. ${ }^{16}$

However, the results in Table 11 show that the decrease in the nonsystematic risk-taking incentives is significantly less for the larger banks: The coefficient on the $\mathrm{D}_{1} * \mathrm{D}_{2} *$ (capital ratio) is significantly negative. The coefficients on the $\mathrm{D}_{1} * \mathrm{D}_{2} *(\mathrm{i}, \mathrm{t})$ and $\mathrm{D}_{1} * \mathrm{D}_{2} *\left(\sigma^{2}\left(\varepsilon_{i, t}\right)\right)$ are significantly positive. The coefficient on the $\mathrm{D}_{1} * \mathrm{D}_{2} *$ (asset

\section{TABLE 10.}

This table shows how the FDICIA differently affects the systematic risk-taking incentives of larger and smaller banks

$$
\begin{aligned}
& \left.\beta_{\mathrm{i}, \mathrm{t}+1}-\beta_{\mathrm{i}, \mathrm{t}}=\mathrm{b}_{0}+\mathrm{b}_{10}(\text { Capital-to-asset })_{\mathrm{i}, \mathrm{t}}+\mathrm{b}_{11} * \mathrm{D}_{1} * \text { (Capital-to-asset }\right)_{\mathrm{i}, \mathrm{t}} \\
& +\mathrm{b}_{12} * \mathrm{D}_{1} * \mathrm{D}_{2} *(\text { Capital-to-asset })_{\mathrm{i}, \mathrm{r}} \\
& +\mathrm{b}_{20}(\text { Market-book })_{\mathrm{i}, \mathrm{t}}+\mathrm{b}_{21} * \mathrm{D}_{1} *(\text { Market-book })_{\mathrm{i}, \mathrm{t}}+\mathrm{b}_{22} * \mathrm{D}_{1} * \mathrm{D}_{2} *(\text { Market-book })_{\mathrm{i}, \mathrm{t}} \\
& +b_{30}\left(\beta_{\mathrm{i}, \mathrm{t}}\right)+\mathrm{b}_{31} * \mathrm{D}_{1} *\left(\beta_{\mathrm{i}, \mathrm{t}}\right)+\mathrm{b}_{32} * \mathrm{D}_{1} * \mathrm{D}_{2} *\left(\beta_{\mathrm{i}, \mathrm{t}}\right) \\
& +b_{40}(\text { Asset })_{i, t}+b_{41} * D_{1} *(\text { Asset })_{i, t}+b_{42} * D_{1} * D_{2} *(\text { Asset })_{i, t}+b_{5}(\text { GDP growth })_{t}+\varepsilon_{i, t}
\end{aligned}
$$

\begin{tabular}{|c|c|}
\hline Independent variables & \\
\hline Intercept & $\begin{array}{c}0.8467 * * \\
(2.18)\end{array}$ \\
\hline$(\text { Capital-to-asset })_{i, t}$ & $\begin{array}{c}-1.8301 \\
(-0.48)\end{array}$ \\
\hline $\mathrm{D}_{1} *(\text { Capital-to-asset })_{\mathrm{i}, \mathrm{t}}$ & $\begin{array}{c}2.1815 \\
(0.73)\end{array}$ \\
\hline $\mathrm{D}_{1} * \mathrm{D}_{2} *(\text { Capital-to-asset })_{i, t}$ & $\begin{array}{c}-0.7184 \\
(-0.13)\end{array}$ \\
\hline$(\text { Market-book })_{i, t}$ & $\begin{array}{c}-0.0061 \\
(-1.48)\end{array}$ \\
\hline $\mathrm{D}_{1} *(\text { Market-book })_{i, \mathrm{t}}$ & $\begin{array}{c}0.0428 * * * \\
(3.31)\end{array}$ \\
\hline $\mathrm{D}_{1} * \mathrm{D}_{2} *(\text { Market-book })_{\mathrm{i}, \mathrm{t}}$ & $\begin{array}{c}-0.0381 * * * * \\
(-2.53)\end{array}$ \\
\hline$\beta_{\mathrm{i}, \mathrm{t}}$ & $\begin{array}{c}-0.9561^{* * * *} \\
(-15.68)\end{array}$ \\
\hline$D_{1} *\left(\beta_{i, \varepsilon}\right)$ & $\begin{array}{c}-0.0762 \\
(-0.98)\end{array}$ \\
\hline $\mathrm{D}_{1} * \mathrm{D}_{2} *\left(\beta_{\mathrm{i}, \mathrm{t}}\right)$ & $\begin{array}{c}0.2061 \\
(0.86)\end{array}$ \\
\hline$(\text { Asset } \text { size })_{i, \mathrm{t}}$ & $\begin{array}{c}7.5 \mathrm{E}-06 * * * \\
(2.53)\end{array}$ \\
\hline$D_{1} *(\text { Asset size })_{i, t}$ & $\begin{array}{c}-1.8 \mathrm{E}-05 \\
(-0.38)\end{array}$ \\
\hline $\mathrm{D}_{1} * \mathrm{D}_{2} *(\text { Asset size })_{\mathrm{i}, \mathrm{t}}$ & $\begin{array}{c}1.21 \mathrm{E}-05 \\
(0.25)\end{array}$ \\
\hline$\%$ GDP & $\begin{array}{c}-4.4655 \\
(-0.87)\end{array}$ \\
\hline $\begin{array}{l}\text { F-statistics } \\
\text { Adjusted } R^{2}\end{array}$ & $\begin{array}{c}54.89 * * * \\
0.55\end{array}$ \\
\hline
\end{tabular}

,where $D_{1}=1$ if after the FDICIA, and 0 otherwise, $D_{2}=1$ if larger asser size group's bank, and 0 otherwise 
TABLE 11.

This table shows how the FDICIA differently affects the nonsystematic risk-taking incentives of larger and smaller banks

$\sigma_{\mathrm{i}, \mathrm{t}+1}-\sigma_{\mathrm{i}, \mathrm{t}} \quad\left\{\right.$ or, $\left.\sigma^{2}\left(\varepsilon_{\mathrm{i}, \mathrm{t}+1}\right)-\sigma^{2}\left(\varepsilon_{\mathrm{i}, \mathrm{t}}\right)\right\}$

$=\mathrm{b}_{0}+\mathrm{b}_{10}(\text { Capital-to-asset })_{\mathrm{i}, \mathrm{t}}+\mathrm{b}_{11} * \mathrm{D}_{1} *(\text { Capital-to-asset })_{\mathrm{i}, \mathrm{t}}+\mathrm{b}_{12} * \mathrm{D}_{1} * \mathrm{D}_{2} *(\text { Capital-to-asset })_{\mathrm{i}, \mathrm{t}}$

$+\mathrm{b}_{20}(\text { Market-book) })_{\mathrm{i}, \mathrm{t}}+\mathrm{b}_{21} * \mathrm{D}_{1} *$ (Market-book) $)_{\mathrm{i}, \mathrm{t}}+\mathrm{b}_{22} * \mathrm{D}_{1} * \mathrm{D}_{2} *$ (Market-book)i,t

$+\mathrm{b}_{30}\left(\sigma_{\mathrm{i}, \mathrm{t}}\right)+\mathrm{b}_{31} * \mathrm{D}_{1} *\left(\sigma_{\mathrm{i}, \mathrm{t}}\right)+\mathrm{b}_{32} * \mathrm{D}_{1} * \mathrm{D}_{2} *\left(\sigma_{\mathrm{i}, \mathrm{t}}\right)\left\{\right.$ or, $\left.\mathrm{b}_{30} 2(\mathrm{i}, \mathrm{t})+\mathrm{b}_{31} * \mathrm{D}_{1} * \sigma^{2}\left(\mathrm{i}_{\mathrm{i}, \mathrm{t}}\right)+\mathrm{b}_{32} * \mathrm{D}_{1} * \mathrm{D}_{2} * \sigma^{2}\left(\varepsilon_{\mathrm{i}, \mathrm{t}}\right)\right\}$

$+b_{40}(\text { Asset })_{i, t}+b_{41} * D_{1} *(\text { Asset })_{i, t}+b_{42} * D_{1} * D_{2} *(\text { Asset })_{i, t}+b_{s}(\text { GDP growth })_{t}+\varepsilon_{i, t}$

,where $\mathrm{D}_{1}=1$ if after the FDICIA, and 0 otherwise, $\mathrm{D}_{2}=1$ if larger asset size group's bank, and 0 otherwise

\begin{tabular}{|c|c|c|}
\hline Independent variables & Dependent $=\sigma_{\mathrm{i}, \mathrm{t}+1}-\sigma_{\mathrm{i}, \mathrm{t}}$ & Dependent $=\sigma^{2}\left(\varepsilon_{\mathrm{i}, \mathrm{t}+1}\right)-\sigma^{2}\left(\varepsilon_{\mathrm{i}, \mathrm{t}}\right)$ \\
\hline Intercept & $\begin{array}{c}0.0336 \\
(1.71)\end{array}$ & $\begin{array}{l}-0.0002 \\
(-0.01)\end{array}$ \\
\hline$(\text { Capital-to-asset })_{i, \mathrm{t}}$ & $\begin{array}{r}-0.0425 \\
(-0.22)\end{array}$ & $\begin{array}{c}0.0492 \\
(0.23)\end{array}$ \\
\hline $\mathrm{D}_{1} *(\text { Capital-to-asset })_{\mathrm{i}, \mathrm{t}}$ & $\begin{array}{c}0.2021 \\
(1.33)\end{array}$ & $\begin{array}{l}0.2063 \\
(1.253)\end{array}$ \\
\hline $\mathrm{D}_{1} * \mathrm{D}_{2} *(\text { Capital-to-asset })_{\mathrm{i}, \mathrm{t}}$ & $\begin{array}{l}-1.7405 * * * \\
(-5.67)\end{array}$ & $\begin{array}{c}-0.9097 * * * \\
(-3.33)\end{array}$ \\
\hline$(\text { Market-book })_{i, t}$ & $\begin{array}{l}-0.0003 \\
(-1.31)\end{array}$ & $\begin{array}{c}-2.4 \mathrm{E}-05 \\
(-0.11)\end{array}$ \\
\hline $\mathrm{D}_{1} *(\text { Market-book })_{i, t}$ & $\begin{array}{l}0.0017 * * * \\
(2.66)\end{array}$ & $\begin{array}{l}0.0018 * * \\
\quad(2.42)\end{array}$ \\
\hline $\mathrm{D}_{1} * \mathrm{D}_{2} *(\text { Market-book })_{\mathrm{i}, \mathrm{t}}$ & $\begin{array}{c}-0.0002 \\
(-0.22)\end{array}$ & $\begin{array}{l}-0.0005 \\
(-0.52)\end{array}$ \\
\hline$\sigma_{\mathrm{i}, \mathrm{t}}$ & $\begin{array}{c}-0.9450 * * * \\
(-13.1)\end{array}$ & \\
\hline $\mathrm{D}_{1} *\left(\sigma_{i, t}\right)$ & $\begin{array}{c}-0.1148 \\
(-1.14)\end{array}$ & \\
\hline $\mathrm{D}_{1} * \mathrm{D}_{2} *\left(\sigma_{\mathrm{i}, \mathrm{t}}\right)$ & $\begin{array}{l}5.3847 * * * \\
(6.68)\end{array}$ & \\
\hline$\sigma^{2}\left(\varepsilon_{i, t}\right)$ & & $\begin{array}{l}-0.9982 * * * \\
(-12.77)\end{array}$ \\
\hline $\mathrm{D}_{1} *\left(\sigma^{2}\left(\varepsilon_{i, t}\right)\right)$ & & $\begin{array}{l}-0.0606 \\
(-0.57)\end{array}$ \\
\hline $\mathrm{D}_{1} * \mathrm{D}_{2} *\left(\sigma^{2}\left(\varepsilon_{\mathrm{i}, \mathrm{t}}\right)\right)$ & & $\begin{array}{l}101.71 * * * \\
\quad(7.60)\end{array}$ \\
\hline$(\text { Asset size })_{i, \mathrm{t}}$ & $\begin{array}{l}-4 \mathrm{E}-08 \\
(-0.27)\end{array}$ & $\begin{array}{l}1.15 \mathrm{E}-08 \\
(0.07)\end{array}$ \\
\hline $\mathrm{D}_{1} *(\text { Asset } \text { size })_{i, \mathrm{t}}$ & $\begin{array}{l}-4.2 \mathrm{E}-06^{*} \\
(-1.74)\end{array}$ & $\begin{array}{l}-3.2 \mathrm{E}-06 \\
(-1.20)\end{array}$ \\
\hline $\mathrm{D}_{1} * \mathrm{D}_{2} *$ (Asset size $)_{i, t}$ & $\begin{array}{l}4.15 \mathrm{E}-06 * \\
\quad(1.72)\end{array}$ & $\begin{array}{l}3.3 \mathrm{E}-06 \\
(1.22)\end{array}$ \\
\hline$\%$ GDP & $\begin{array}{c}-0.0598 \\
(-0.23)\end{array}$ & $\begin{array}{l}-0.0443 \\
(-0.15)\end{array}$ \\
\hline $\begin{array}{l}\text { F-statistics } \\
\text { Adjusted } \mathrm{R}^{2}\end{array}$ & $\begin{array}{l}33.15 * * * \\
0.42\end{array}$ & $\begin{array}{c}34.01 * * * \\
0.43 \\
\text { aded from Bri } 0.4304 / 26 / 2023 \quad 12\end{array}$ \\
\hline
\end{tabular}


size) is significantly positive. The coefficient on the $D_{1} * D_{2} *$ (franchise value) is negative, though insignificant. Thus, after the FDICIA, even though the larger banks' decrease in the systematic risk-taking incentives was somewhat or insignificantly less than that of the smaller banks, their decrease in the nonsystematic incentives was significantly less than that of the smaller banks. Furthermore, the signs of their change in the nonsystematic incentives themselves were mixed, as reflected in the signs of the sum of the coefficients on $D_{1}$ and $D_{1} * D_{2}$ interaction variables in Table 11. These empirical findings are similarly observed for the lower/higher capital ratio banks.

Overall, these empirical results show that, after the FDICIA, the decrease in the risk-taking incentives of the higher moral hazard incentive banks (larger and lower capital ratio banks) was less than that of the lower moral hazard incentive banks (smaller and higher capital ratio banks), with respect to both systematic and nonsystematic risk-taking measures. This result may have the policy implication that regulatory agents should monitor higher moral hazard incentive banks more closely and frequently. Furthermore, the fact that even the signs of the change of their nonsystematic risk-taking incentives have been mixed suggests that regulators should allocate more time and effort toward monitoring the nonsystematic risk-taking behavior of higher moral hazard incentive banks, as long as that is positively related to bank failure.

\section{Test for the Effects of the FDICIA on Banks' Risk-taking Incentives Using Balance Sheet Risk Measure}

We estimated how the banks' risk-taking incentives changed with the FDICIA, using loan-to-asset ratio as the measure of the bank's current risk level, which is widely used as a balance sheet risk measure in the literature. ${ }^{17} \mathrm{~A}$ higher proportion of loans generally tend to increase the risk of the bank: the higher the current loan-to-asset ratio is, the more vulnerable the future performance of the bank is to future economic conditions.

The result in Table 12 shows that lower capital-ratio banks tended to take on greater loan incremental policies before the FDICIA, though insignificant. However, the significantly positive coefficient on the $D^{*}$ (capital ratio) indicates that the moral hazard incentives of the stockholders regarding loan incremental policies were significantly decreased after the FDICIA. It is also seen that the coefficient on the (loan ratio) $)_{t}$ is negative, indicating that the banks do not have perverse incremental risk incentives associated with the current risk level. The significantly negative coefficient on the $\mathrm{D} *$ (loan ratio) indicates that those incentives decreased significantly after the FDICIA. The coefficients on the franchise value and asset size are insignificant, both before and after the FDICIA. The negative relationship between asset size and loan incremental may be interpreted in terms of the smaller banks' desire for rapid growth by expanding loans. 


\section{TABLE 12.}

This table shows how the FDICIA affects the risk-taking incentives of the banks, using loan-to-asset ratio as the balance sheet risk measure.

$$
\begin{aligned}
& (\text { Loan-to-asset })_{i, t+1}-(\text { Loan-to-asset })_{i, \mathrm{t}}=\mathrm{b}_{0}+\mathrm{b}_{10}(\text { Capital-to-asset })_{\mathrm{i}, \mathrm{t}}+\mathrm{b}_{11} * \mathrm{D} *(\text { Capital-to-asset })_{\mathrm{i}, \mathrm{t}} \\
& +b_{20}(\text { Market-book })_{i, t}+b_{21} * \mathrm{D} *(\text { Market-book })_{i, t} \\
& \left.\left.+b_{30} \text { (Loan-to-asset }\right)_{i, t}+b_{31} * D^{*} \text { (Loan-to-asset }\right)_{i, t} \\
& +b_{40}(\text { Asset })_{i, t}+b_{41} * D *(\text { Asset })_{i, t}+b_{5}(\text { GDP growth })_{t}+e_{i, t}
\end{aligned}
$$

\begin{tabular}{|c|c|c|}
\hline Independent variables & $\begin{array}{c}\text { Predicted sign associated with } \\
\text { the FDICIA }\end{array}$ & \\
\hline Intercept & & $\begin{array}{l}-0.0306 \\
(-1.03)\end{array}$ \\
\hline$D^{*}($ Intercept $)$ & & $\begin{array}{l}0.0457 \\
(1.15)\end{array}$ \\
\hline$(\text { Capital-to-asset })_{i, t}$ & & $\begin{array}{c}-0.1317 \\
(-0.63)\end{array}$ \\
\hline $\mathrm{D}^{*}(\text { Capital-to-asset })_{\mathrm{i}, \mathrm{t}}$ & $b_{11}:(+)$ & $\begin{array}{c}0.6436 * * \\
(1.97)\end{array}$ \\
\hline$(\text { Market-book })_{\mathrm{i}, \mathrm{t}}$ & & $\begin{array}{c}7.07 \mathrm{E}-05 \\
(0.34)\end{array}$ \\
\hline $\mathrm{D} *(\text { Market-book })_{\mathrm{i}, \mathrm{t}}$ & $b_{21}:(+)$ & $\begin{array}{c}7.19 \mathrm{E}-05 \\
(0.19)\end{array}$ \\
\hline$(\text { Loan-to-asset })_{i, t}$ & & $\begin{array}{c}-0.0193 \\
(-0.63)\end{array}$ \\
\hline$D^{*}(\text { Loan-to-asset })_{i, t}$ & $b_{31}:(-)$ & $\begin{array}{c}-0.1195 * * * \\
(-2.71)\end{array}$ \\
\hline$\left(\right.$ Asset size $_{\mathrm{i}, \mathrm{t}}$ & & $\begin{array}{c}-1.1 \mathrm{E}-07 \\
(-0.75)\end{array}$ \\
\hline $\mathrm{D}^{*}(\text { Asset size })_{\mathrm{i}, \mathrm{t}}$ & $b_{41}:(-)$ & $\begin{array}{l}-7 \mathrm{E}-08 \\
(-0.36)\end{array}$ \\
\hline$\% \mathrm{GDP}$ & & $\begin{array}{c}0.8344 * * * \\
(3.39)\end{array}$ \\
\hline $\begin{array}{l}\text { F-statistics } \\
\text { Adjusted } R^{2}\end{array}$ & & $\begin{array}{c}4.52 * * \\
0.06\end{array}$ \\
\hline
\end{tabular}

, where $\mathrm{D}=1$ if after the FDICIA, and 0 otherwise

\section{CONCLUSION}

This study empirically examines how the Federal Deposit Insurance Corporation Improvement Act (FDICIA) of 1991 in the U.S. banking industry affected the moral hazard risk-taking incentives of banks. We find that the FDICIA appears to have been effective in significantly reducing the systematic risk-taking incentives of the banks. Considering that the banks' asset portfolios are, necessarily, largely systematic risk-related, the significant decrease in their systematic risk-taking in- 
centives provides some evidence for the effectiveness of the FDICIA. However, with respect to the nonsystematic risk-taking behavior, the results generally indicate a statistically insignificant decrease in the risk-taking incentives after the FDICIA. To well-diversified investors who can diversify nonsystematic risk away, nonsystematic risk may not be a risk any more. However, to maintain a sound banking environment and to reduce the risk factor of individual banks, this result implies that regulatory agents should monitor the banks' nonsystematic risk-taking behavior more closely, as long as it is positively related to the banks' failures. We further tested the change in the risk-taking incentives by partitioning the full sample into two groups: banks with higher moral hazard incentives as those with larger asset size and lower capital ratio, and banks with lower moral hazard incentives as those with smaller asset size and higher capital ratio. The main result for this test is that, with the FDICIA, the decrease in the risk-taking incentives of the banks with higher moral hazard incentives (larger asset-size and lower capital-ratio banks) is less than that of the banks with lower moral hazard incentives (smaller asset-size and higher capital-ratio banks), with respect to both systematic and nonsystematic risk-taking measures. Furthermore, the change in the nonsystematic risk-taking incentives of the banks with higher moral hazard incentives is rather mixed, while their systematic incentives are decreased. These findings imply that the regulatory agents should allocate more time and effort toward monitoring the banks with higher moral hazard incentives with particular emphasis on their nonsystematic risk-taking behavior.

\section{REFERENCES}

Acharya, S. 1996. Charter Value, Minimum Bank Capital Requirement and Deposit Insurance Pricing in Equilibrium. Journal of Banking and Finance 20: 351-375. Akhavein, J. D., Berger, A. N., and Humphrey, D. B. 1997. The Effects of Bank Megamergers on Efficiency and Prices. Review of Industrial Organization 12. Allen, P. R and Wilhelm, W. J. 1988. The Impact of the 1980 Depository Institutions Deregulations and Monetary Control Act on Market Value and Risk. Journal of Money, Credit, and Banking 20: 364-380.

Bernanke, B. S. and Lown, C. S. 1991. The Credit Crunch, Brookings Papers on Economic Activity 2: 205-248.

Bundt, T. P., Cosimano, T. F., and Halloran, J. A. 1992. DIDMCA and Bank Market Risk: Theory and Evidence. Journal of Banking and Finance 16: 1179-1193.

Demsetz, R. S., Saidenberg M. R., and Strahan P. E. 1997. Agency Problems and Risk Taking at Banks. Federal Reserve Bank of New York Economic Review. Demsetz, R. S., and Strahan, P. E. 1997. Diversification, Size, and Risk at Bank Holding Companies. Journal of Money, Credit, and Banking 29: 300-313.

Esty, B. C. 1997. Organizational Form and Risk Taking in the Savings and Loan 
Industry. Journal of Financial Economics 44: 25-55.

Fama, E. F. 1985. What's Different about Banks. Journal of Monetary Economics 15: 29-39.

Flood, M. D. 1993. Deposit Insurance : Problems and Solutions. Federal Reserve Bank of St. Louis Economic Review: 28-33.

Furlong, F. T. and Keeley, M. C. 1989. Capital Regulation and Bank Risk-Taking: A Note. Journal of Banking and Finance 13: 883-891.

Galloway, T. M., Lee, W. B., and Roden. D. M. 1997. Banks' Changing Incentives and Opportunities for Risk Taking. Joumal of Banking and Finance 21: 509-527. Gernnote, G., and Pyle, D., 1991. Capital Controls and Bank Risk. Journal of Banking and Finance 15: 805-824.

Grossman, R. S. 1992. Deposit Insurance, Regulation, and Moral Hazard in the Thrift Industry: Evidence from the 1930's. American Economic Review 82: 800-821. Gunther, J. W. and Robinson, K. J. 1990. Empirically Assessing the Role of Moral Hazard in Increasing the Risk Exposure of Texas Banks. Federal reserve Bank of Dallas Economic Review.

Horvitz, P. M. 1983. The Case Against Risk-Related Deposit Insurance Premiums. Housing Finance Review: 253-268.

James, C. 1987. Some Evidence of the Uniqueness of Bank Loans. Journal of Financial Economics 19: 217-235.

Kaufman, G. G. 1994. The current State of Banking Reform. Research in Financial Services 6: 281-312.

Keeley, M. C. 1990. Deposit Insurance, Risk, and Market Power in Banking. American Economic Review 80: 1183-1200.

Mckenzie, J. A., Cole, R. A., and Brown, R. A. 1992. Moral Hazard, Portfolio Allocation, and Asset returns for Thrift Institutions. Journal of Financial Services Research: 315-339.

Merton, R. C. 1977. An Analytical derivation of the Cost of Deposit Insurance and Loan Guarantees. Journal of Banking and Finance 1: 3-11.

O'Hara, M. and Shaw, W. 1990. Deposit Insurance and wealth Effects: The Value of Being "Too Big to Fail. Journal of Finance 5: 1587-1600.

Osborne, D. K. and Zaher, T. S. 1992. Reserve Requirements, Bank Share Prices, and the Uniqueness of Bank Loans. Journal of Banking and Finance 16: 799-812.

Peltzman, S. 1976. Toward a More General Theory of Regulation. Journal of Law and Economics 19: 211-241.

Ronn, E. I. and Verma, A. K. 1986. Pricing Risk-Adjusted Deposit insurance: An Option-Based model. Journal of Finance: 871-895.

Ronn, E.I., and Verma, A.K., 1989. Risk-Based Capital Adequacy for a Sample of 43 Major Banks. Journal of Banking and Finance 13: 21-29.

Saunders, A., Strock, E., and Travlos N.G., 1990. Ownership Structure, Deregulation, and Bank Risk Taking. Journal of Finance 2: 643-654.

Sundaram, S., Rangan, N., and Davidson, W. N. 1992. The Market Valuation 


\section{Effects of the Financial Institutuions Reform, Recovery and Enforcement Act of 1989. Journal of Banking and Finance 16: 1097-1122.}

\section{ENDNOTES}

${ }^{1}$ However, as Galloway, Lee and Roden (1997) note, a contemporaneous relation might simply reflect a bank's superior performance and not necessarily its intentions to take on less risk.

2 However, with respect to nonsystematic risks (standard deviation of stock returns and unsystematic risk), the results are somewhat mixed, though generally insignificant.

3 However, with respect to systematic risk measures $(\beta)$, their results are insignificant.

${ }_{5}^{4}$ Of course, merger case can be controlled by including the dummy variable.

${ }^{5}$ In this study, we estimate both systematic and unsystematic measures form a one-factor market model using the S\&P 500 as the market model. There is no specific reason why we use the one-factor market model in estimating these two risk measures. In banking literature, both the one-factor model and the two-factor model are widely used. In the case where the two-factor market model is used, the two factors are normally the market portfolio and the interest rate:

${ }^{6}$ We define risk-taking as the incremental risk of the bank. That is, as described in 3.2 and 3.3 (4), we use the level of current risk as one control variable affecting bank risk-taking behavior. As discussed in 3.3 (4), the intuition for this argument is as follows: Before the FDICIA, the overall risk factor of the bank was not an explicit target of regulations. However, after the FDICIA, when regulatory oversights and constraints would be imposed more heavily on the banks with higher risk factors through many provisions of the FDICIA such as risk-based insurance premiums, riskier banks are expected to improve their risk status more than safer banks.

The studies using $\beta$ as the risk measure include Allen and Wilhelm (1988), Bundt, Cosimano and Halloran (1992), Demsetz, Saidenberg and Strahan (1997), Saunders, Strock and Travlos (1990) and Sundaram, Rangan and Davidson (1992) and others. The studies using $\sigma$ as the risk measure include Demsetz, Saidenberg and Strahan (1997), Demsetz and Strahan (1997), Galloway, Lee and Roden (1997), Saunders, Strock and Travlos (1990) and others. The study using $\sigma^{2}(\varepsilon)$ as the risk measure includes Saunders, Strock and Travlos (1990).

${ }^{8}$ We do not include the ownership structure as one variable in this research, because the sign of the relationship between risk-taking and ownership structure lacks consensus in the literature.

9 When we employ the employment growth rate, we find very similar results through the research.

${ }^{10}$ The event studies using regression analysis with dummy variables were by Allen and Wilhelm (1988), Bundt, Cosimano and Halloran (1992), and Sundaram, Rangan and Davidson (1992), Saunders, Strock and Travlos (1990), and so on. On the other hand, the studies using traditional event-study methods were by James (1987), Kolari, Mahajan and Saunders (1988), and Osborne and Zaher (1992), and so on.

${ }^{11}$ In the estimation equation (1), since the dummy variable D Takes 0 before the FDICIA, b $b_{\mathrm{i} 1}$ terms go away, and only the $b_{i 0}$ terms are left. Thus, the coefficients on the $b_{i 0}$ terms reflect those for the pre- FDICIA period. After the FDICIA, since the dummy variable takes 1 , the coefficient on each independent variable becomes $b_{i 0}+b_{i 1}$. Thus, the coefficients on the bil terms are the incremental coefficients relating to each independent variable and $\Delta \beta$ for the post-FDICIA period.

${ }^{12}$ Researchers argue that lower franchise value and larger asset size banks pursue riskier strategies. Thus, we expected a negative correlation between these two variables.

${ }_{11}^{13}$ These two year dummy variables are arbitrarily chosen, with no theoretical reason.

${ }_{15}^{14}$ These results are available from the author.

${ }^{15}$ Peltzman (1976) notes that 'due to possible asymmetry among the position of the industry's members, the legislation may differentially affect the welfare of those members'.

${ }^{16}$ Though larger banks reduce their systematic risk-taking incentives less than those of the smaller banks, they reduce their incentives, themselves, with the FDICIA, as reflected in the signs of the sum of the coefficients on $\mathrm{D}_{1}$ and $\mathrm{D}_{1} * \mathrm{D}_{2}$ interaction variables.

${ }^{17}$ The studies using loan-to-asset ratio as the balance sheet risk measure were by Demsetz, Saidenberg and Strahan (1997), Gunther and Robinson (1990), and Bernanke and Lown (1991). 